\title{
ABSTRACTS FROM THE TECHNICAL SESSIONS OF THE FIRST U. S. GEOLOGICAL SURVEY WATER-QUALITY WORKSHOP, NORTHEASTERN REGION, SKYLAND, VIRGINIA, MARCH 31 - APRIL 3, 1986
}

By Carolyn J. Oblinger Childress and Charlene C. Vince, compilers

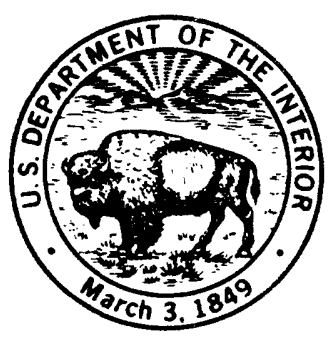

Columbus, Ohio 1991 


\section{U.S. DEPARTMENT OF THE INTERIOR}

MANUEL LUJAN, JR., Secretary

U.S. GEOLOGICAL SURVEY

Dallas L. Peck, Director

The use of brand, company, or trade names in these abstracts is for identification purposes only and does not constitute endorsement by the U.S. Geological Survey.

For additional information write to:

District Chief Water Resources Division U.S. Geological Survey $975 \mathrm{~W}$. Third Avenue Columbus, Ohio 43212-3192
Copies of this report can be purchased from:

U.S. Geological Survey Books and Open-File Reports Box 25425, Federal Center Building 810

Denver, CO 80225 


\section{PREFACE}

The First Northeastern Region Water-Quality Workshop was held at Skyland Lodge, Shenandoah National Park, Virginia, during March 31-April 3, 1986, and was attended by water-quality technical staff primarily from the Northeastern Region of the U.S. Geological Survey, Water Resources Division. The workshop was conceived and organized to facilitate the exchange of information among Districts within the Region. It provided an opportunity for District staff to meet and share technical information on water-quality studies and on ideas for water-quality-program development. States within the Northeastern Region of the Water Resources Division share many concerns about water-resources issues such as ground-water contamination, nonpoint-source contamination of surface and ground water by agricultural chemicals and urban land uses, and acid rain. Furthermore, a particular District's approaches and solutions to challanges in data collection or analysis can be useful and transferable to studies in another District.

The workshop was organized into topical sessions on quality assurance, isotopes of hydrogen and oxygen, acid rain, acid water, water quality and land use, methods for data interpretation, water-quality trends, field methods, and yinund-water contamination/ground-water field methods. The workshop was opened by Wayne Webb, Northeastern Region Water-Quality Specialist, with a brief statement of the purpose and objectives of the workshop. Two invited speakers joined the workshop on the second morning: Stanley P. Sauer, Regional Hydrologist, Northeastern Region, shared his perspective on the direction of water-quality activities in the Region, and David A. Rickert, Chief, Office of Water Quality, Water Resources Division, described the role of the Office of Water Quality. This report contains the abstracts of oral presentations that describe the results of research and applied water-quality studies within the Northeastern Region. Abstracts are arranged in the order in which they were presented.

Carolyn J. Oblinger Childress

Hydrologist 
CONTENTS

Page

PREFACE

iii

WATER-QUALITY DATA-COLLECTION ACTIVITIES IN OHIO:

PHASE II-QUALITY-ASSURANCE PRACTICES IN SAMPLE

COLLECTION AND LABORATORY ANALYSIS

Carolyn J. Oblinger Childress and Donna N. Myers

ANALYSIS OF QUALITY-ASSURANCE SAMPLES COLLECTED

DURING AN INVESTIGATION OF HAZARDOUS-WASTE-

DISPOSAL FACILITIES IN LOGAN TOWNSHIP, GLOUCESTER COUNTY, NEW JERSEY

Joseph J. Hochreiter, Jr., Jane Kozinski, and Jean C. Lewis

OXYGEN AND HYDROGEN STABLE-ISOTOPE RATIOS AS

AN AID TO INTERPRETING HYDROGEOLOGIC AND

CHEMICAL-QUALITY DATA

Jeffrey T. de Roche and Kevin J. Breen

ESTIMATES OF STREAM LEAKAGE AND HYDRAULIC PROPERTIES OF A GLACIAL AQUIFER NEAR DOVER, NEW JERSEY, BASED ON THE CHEMICAL CHARACTER OF WATER, INCLUDING STABLE ISOTOPES OF HYDROGEN AND OXYGEN

Joel E. Dysart .

THE USE OF DEUTERIUM AND OXYGEN-18 TO TRACE THE MOVEMENT OF INDUCED RIVER RECHARGE INTO THE POTOMAC-RARITAN- MAGOTHY AQUIFER SYSTEM, CAMDEN AREA, NEW JERSEY

Steven D. McAuley, Carol Kendall, and Thomas V. Fusillo.

USE OF REGRESSION ANALYSIS AND TIME SERIES METHODS FOR ESTIMATING CHEMICAL LOADS FOR TWO HYDROLOGICALLY DISSIMILAR STREAMS

Rochelle Rittmaster

Presenter is in bold type 
STREAM CHEMISTRY RESPONSE DURING EPISODES OF

ACIDIC RAINFALL AND SNOWMELT RUNOFF ON LAUREL

HILL, SOMERSET COUNTY, PENNSYLVANIA,

NOVEMBER 1983 TO JULY 1985

E. C. Witt, III and J. L. Barker

STREAM ACIDIFICATION IN THE CATSKILL MOUNTAINS OF NEW YORK

Peter S. Murdoch and Charles R. Barnes

SENSITIVITY OF STREAM BASINS IN SHENANDOAH NATIONAL

PARK TO ACID DEPOSITION

Dennis D. Lynch and Nancy B. Dise

DUAL-ACIDITY-TITRATION CURVES-FINGERPRINT, INDICATOR OF REDOX STATE, AND ESTIMATOR OF IRON AND ALUMINUM CONTENT OF ACID-MINE DISCHARGE AND RELATED WATERS Arthur N. Ott

THEORETICAL TECHNIQUE FOR DETERMINING THE CUMULATIVE IMPACT OF IRON AND MANGANESE OXIDATION IN STREAMS RECEIVING DISCHARGE FROM COAL MINES Keith E. Bobay

FACTORS AFFECTING ACIDIC GROUND-WATER CONTAMINATION AT A SURFACE COAL MINE IN WESTERN PENNSYLVANIA John H. Williams and Kenn L. Pattison

PREIMPOUNDMENT WATER QUALITY OF SWATARA CREEK, PENNSYLVANIA

David K. Fishel

EVIDENCE FOR LEACHING OF TRACE-METALS FROM PLUMBING MATERIALS EXPOSED TO ACIDIC GROUND WATER IN SELECTED AREAS OF THE NEW JERSEY COASTAL PLAIN George R. Kish and Jo Ann Macy

SEDIMENT-NUTRIENT DYNAMICS AND SEDIMENT-OXYGEN DEMAND IN THE TIDAL PATUXENT RIVER AND ESTUARY, MARYLAND

Bruce M. Lantrip and Robert M. Summers 
GROUND-WATER QUALITY AS RELATED TO HOUSING

DENSITY, CAPE COD, MASSACHUSETTS

James H. Persky

PRELIMINARY STUDY OF THE RELATION BETWEEN LAND

USE AND GROUND WATER QUALITY OF THE UPPER

GLACIAL AQUIFER IN NASSAU AND SUFFOLK COUNTIES, LONG ISLAND, NEW YORK

David A. Eckhardt, Edward T. Oaksford, and W. Flipse, Jr.

PRELIMINARY ASSESSMENT OF WATER QUALITY AND

ITS RELATION TO HYDROGEOLOGY AND LAND USE:

POTOMAC- RARITAN-MAGOTHY AQUIFER SYSTEM,

CENTRAL NEW JERSEY

Eric F. Vowinkel, Cynthia Barton, and John Nawyn

CHEMISTRY OF WATER IN AN UNCONFINED AQUIFER

UNDER AN IRRIGATED FIELD IN EASTERN SUSSEX

COUNTY, DELAWARE

Judith M. Denver

EFFECTS OF AGRICULTURAL-MANAGEMENT PRACTICES ON SURFACE AND GROUND-WATER QUALITY OF A SMALL CARBONATE BASIN, CONESTOGA RIVER BASIN, PENNSYLVANIA

Patricia L. Lietman

A COMPARISON OF SELECTED WATER-QUALITY CHARACTERISTICS IN ACCOUNTING UNIT 070102, UPPER MISSISSIPPI RIVER BASIN, ROYALTON TO HASTINGS, MINNESOTA

Mark R. Have

HYDROGEOLOGY AND WATER QUALITY OF THE CATOCIN MOUNTAIN, NATIONAL PARK AREA, FREDERICK COUNTY, MARYLAND

Thomas Trombley (No Abstract)

AUTOMATIC DATA RETRIEVAL AND PROCESSING SYSTEM(ADAREPS).

Peter Hughes 
AN AUTOMATED METHOD FOR SUBDIVIDING SUSPENDEDSEDIMENT AND CHEMICAL RECORDS

RELIABILITY OF WATER QUALITY PREDICTED FROM REGRESSION EQUATIONS

THE MANAGEMENT AND USE OF ORGANIC NONPRIORITYPOLLUTANT DATA

Jane Kozinski, Joseph J. Hochreiter, and Eric F. Vowinkel.

THE IMPORTANCE OF ORGANIC MATTER IN THE

INTERPRETATION OF SURFACE-WATER SEDIMENT DATA

James A. Smith, P. J. Witkowski, and T. V. Fusillo

EQUATION TO ESTIMATE REAERATION COEFFICIENTS IN MASSACHUSETTS STREAMS

Gene W. Parker and Frederick B. Gay

RELATION OF POLYCHLORINATED BIPHENYL TRANSPORT

IN THE UPPER HUDSON RIVER TO POLYCHLORINATED

BIPHENYL CONCENTRATIONS IN RIVER BIOTA

Charles R. Barnes, Mark P. Brown, and Ronald J. Sloan

TEMPORAL CHANGES IN SULFATE, CHLORIDE, AND

SODIUM CONCENTRATIONS IN FOUR EASTERN

PENNSYLVANIA STREAMS

J. Barker (No Abstract)

WATER-QUALITY TRENDS OF MAJOR RIVERS IN WEST VIRGINIA

Theodore A. Ehlke

WATER QUALITY TRENDS IN WHITE RIVER NEAR INDIANAPOLIS, INDIANA: EFFECTS OF ADVANCED TREATMENT OF MUNICIPAL WASTEWATER

David J. Wangness and Charles G. Crawford 
DETERMINATION OF BENTHIC-INVERTEBRATE INDICES

AND WATER- QUALITY TRENDS OF SELECTED STREAMS

IN CHESTER COUNTY, PENNSYLVANIA, 1969-80

Craig R. Moore.

REGIONAL WATER-QUALITY TRENDS AND OFFSHORE EXTENT OF FRESHWATER IN THE 800-FOOT SAND OF THE KIRKWOOD FORMATION, ATLANTIC CITY AREA, NEW JERSEY Jeffrey S. Clark

AN ADAPTATION FOR A TRUSTY OLD WATER SAMPLER Frederick B. Gay. (No Abstract)

COMPARISON OF THREE TYPES OF WATER-QUALITY MONITOR SYSTEMS

Max S. Katzenbach

GUIDELINES FOR USING THE STEADY-STATE GAS-TRACER METHOD TO DETERMINE GAS-DESORPTION COEFFICIENTS Gene W. Parker and Victoria J. Epstein

ELECTRICAL POTENTIALS IN WATERS FROM A STREAMAQUIFER SYSTEM IN A GLACIAL TERRANE NEAR WOOSTER, NORTH-EASTERN OHIO-VARIATIONS AND HYDROLOGIC IMPLICATIONS

Kevin J. Breen

EFFECTS OF SELECTED SAMPLING EQUIPMENT AND PROCEDURES ON TRICHLOROETHYLENE CONCENTRATIONS IN GROUND-WATER SAMPLES

Kenneth A. Pearsall and David A. V. Eckhardt

FIELD EVALUATION OF SAMPLING DEVICES FOR PURGEABLE ORGANIC COMPOUNDS IN GROUND WATER

Thomas E. Imbrigiotta, Jacob Gibs, Thomas V. Fusillo, George R. Kish, and Joseph J. Hochreiter

A STUDY TO EVALUATE THE EFFECTIVENESS OF HIGHWAYDRAINAGE SYSTEMS IN PREVENTING GROUND-WATER CONTAMINATION

Peter E. Church 
MONITOR-WELL INSTALLATION AND INVESTIGATION FOR

VOLATILE ORGANICS CONTAMINATION IN MULTILAYERED

COASTAL PLAIN AQUIFER SYSTEM OF VIRGINIA

Winfield G. Wright, John D. Powell, and David L. Nelms

LARGE-SCALE NATURAL-GRADIENT TRACER TEST IN A SAND

AND GRAVEL AQUIFER, CAPE COD, MASSACHUSETTS

Kathryn M. Hess, Stephen P. Garabedian, Dennis R. LeBlanc,

and Richard D. Quadri

GROUND-WATER POLLUTION IN AN OUTCROP AREA OF

A COASTAL PLAIN AQUIFER SYSTEM: LOGAN TOWNSHIP, NEW JERSEY

Joseph J. Hochreiter, Jr.

(No Abstract)

WELL DESIGN FOR VERTICAL WATER-QUALITY PROFILING IN A SAND AND GRAVEL AQUIFER, CAPE COD, MASSACHUSETTS

Richard D. Quadri and Dennis R. LeBlanc 33 


\title{
WATER-QUALITY DATA-COLLECTION ACTIVITIES IN OHIO: PHASE II- QUALITY-ASSURANCE PRACTICES IN SAMPLE COLLECTION AND LABORATORY ANALYSIS
}

\author{
Carolyn J. Oblinger Childress and Donna N. Myers, \\ U.S. Geological Survey \\ Water Resources Division \\ 975 West Third Avenue \\ Columbus, $\mathrm{OH} 43212-3192$
}

\begin{abstract}
Serious questions have been raised by Congress about the usefulness of existing water-quality data for addressing issues of regional and national scope and, especially, for characterizing current quality of the Nation's streams and ground water. In response, the U.S. Geological Survey has undertaken a pilot project in Colorado and Ohio to determine how well data from current water-quality datacollection activities of Federal, Regional, State, and local agencies and universities can be used to improve our ability to answer three major questions of regional and national scope:
\end{abstract}

1. What are near-natural water-quality conditions?

2. What are existing water-quality conditions?

3. Has water quality changed?

The overall objective of this study is to determine the extent to which existing water data, collected by different groups for various purposes and using different procedures, can be aggregated for use in addressing waterquality questions of regional and national scope.

Specific goals are:

1. Determine the characteristics of current (1984) waterquality programs, including methods of sample collection, laboratory analysis, and data storage by Federal, regional, State, and local agencies, and by academic institutions.

2. Determine the costs of water-quality data-collection programs.

3. Evaluate the applicability of existing data for addressing selected water-quality questions of regional and national scope.

A three-phase approach was used; the objectives of these phases are:

Phase I-identify and inventory water-quality datacollection programs, including costs, and identify those programs that meet a set of broad criteria for conducting water-quality assessments.
Phase II-Inventory and evaluate the quality assurance of sampling techniques and laboratory methods in collecting the data that meet the broad criteria of Phase I, and determine if these data can be aggregated to form reliable data bases.

Phase III-Evaluate the applicability of these qualifying data for addressing selected water-quality questions of regional and national scope.

Phase II focused on the issues of laboratory and field quality assurance and availability of ancillary data. These issues are central to aggregating diverse data bases into one reliable data base, because the comparability of data from different sources depends on how reliably each sample represents instream or in-aquifer conditions.

To address the issue of quality assurance and the availability of ancillary data, the following approach was used in Phase II:

1. Specific criteria were developed for evaluating the quality, comparability, and representativeness of waterquality data and the availability of important ancillary data .

2. Two questionnaires were prepared: The first addrussed field sampling techniques, the second laboratory-analysis techniques.

3. Responses to the questionnaires were compiled and screened based on specific criteria developed in number 1 above.

Only 40 percent of the analyses entering Phase II remained after applying Phase II screening criteria. Sample-collection-technique criteria accounted for the greatest loss. Thirty-six percent of analyses entering Phase II were from samples that had been "grab" collected without knowledge of mixing conditions. Twent $y$ one percent of analyses were screened out because of inadequate laboratory quality assurance-most commonly, a lack of intralaboratory or interlaboratory testing using audit samples. 
In general, there was uniformity of analytical methods. An exception was the analysis of suspended sediments. Only the U.S. Geological Survey uses a method developed specifically for suspended sediments. All other agencies studied used a method developed for total nonfilterable residue, a method not recommended for use by the National Handbook of Recommended Methods for Water Data Acquisition ((U.S. Geological Survey, Office of Water Data Coordination, 1979).

\section{ANALYSIS OF QUALITY-ASSURANCE SAMPLES COLLECTED DURING AN INVESTIGATION OF HAZARDOUS-WASTE-DISPOSAL FACILITIES IN LOGAN TOWNSHIP, GLOUCESTER COUNTY, NEW JERSEY}

\author{
Joseph J. Hochreiter, Jr., and Jane Kozinski \\ Formerly with U.S. Geological Survey \\ Water Resources Division \\ West Trenton, NJ
}

\author{
Jean C. Lewis, \\ U.S. Geological Survey \\ Water Resources Division \\ 810 Bear Tavern Road, Suite 206 \\ West Trenton, NJ 08628
}

A quality-assurance program was developed for a groundwater-quality sampling project implemented at four hazardous-waste-disposal facilities in Logan Township, Gloucester County, New Jersey. The program includes collection of triplicate sample sets, trip blanks, and wash blanks. Standard reference samples for purgeable organic compounds also were analyzed. About 30 percent of the project's total analytical budget was dedicated to qualityassurance testing. For each triplicate sample set, two samples were sent to one of the U.S. Geological Survey Central Laboratories, whereas the third sample was sent to a contract laboratory for analysis. The two U.S. Geological laboratories were considered as one laboratory for the purpose of reporting results from the quality assurance program. Triplicate sample sets were analyzed for a variety of inorganic and organic constituents, including organic compounds not found on the U.S. Environmental Protection Agency priority-pollutant list.

Few guidelines were available for evaluating the analytical precision of the constituents studied. Published precision limits were used in the analysis of data where possible. A rigorous analysis of analytical precision could not always be performed because the concentrations of constituents determined in this study commonly exceeded the range used to develop the published precision limits.

An evaluation of quantitative data from replicate sample sets revealed that, in general, interlaboratory and intralaboratory analytical precision was acceptable for most constituents analyzed . Certain constituents, though, were consistently analyzed in the U.S. Geological Survey lab with precision beyond acceptable limits. These constituents included total organic carbon, polychlorinated biphenyls, methylene chloride, zinc, lead, and arsenic. The precision with which the U.S. Geological Survey lab was able to tentatively identify nonpriority pollutant compounds in replicate sample pairs appeared to be good, however no guidelines exist for objectively evaluating such performance. The degree of precision attained for these analyses seemed to be affected by the amount of time spent analyzing the data, along with the experience of the mass spectroscopist.

On occasion, safety considerations within the U.S. Geological Survey lab required project personnel to reveal the identities of disguised replicate samples. Current laboratory policy does not permit the submission of contaminated samples without detailed supporting documentation. This requirement limited the effectiveness of the quality-assurance program.

Wash blank samples were collected to determine the effectiveness of the cleaning process employed in our study. To eliminate cross contamination between sampling sites, pumping samplers, used for obtaining ground-water samples, were cleaned after each use. The use of large quantities of deionized water alone for cleaning the pump was found to be inadequate for removing highly contaminated ground water from teflon and stainless steel surfaces.

As a result of sample dilutions, the U.S. Geological Survey lab in Denver varied the minimum reporting limits for organic constituents more frequently and to a greater extent than did the U.S. Geological Survey lab in Atlanta or the contract lab. Minimum reporting limits above $10 \mu \mathrm{g} / \mathrm{L}$ occasionally prevented the identification of contaminants in water samples at concentrations that could have been environmentally significant. Some samples were lost or destroyed in the Central Laboratory, and the holding times were exceeded for many samples. Finally, analysis of trip blank samples revealed that an outside source should probably not supply "pure water" trip blank samples. When contamination was found in such samples, the source of the contaminants could not be identified. "Pure water" samples should be prepared and quality checked immediately preceding their use as trip blanks. 


\section{OXYGEN AND HYDROGEN STABLE-ISOTOPE RATIOS AS AN AID TO INTERPRETING HYDROGEOLOGIC AND CHEMICAL-QUALITY DATA}

\author{
Jeffrey $\mathrm{T}$. de Roche \\ U.S. Geological Survey \\ Water Resources Division \\ 975 West Third Avenue \\ Columbus, $\mathrm{OH} 43212$
}

\author{
Kevin J. Breen, \\ U.S. Geological Survey \\ Water Resources Division \\ 840 Market Street \\ Lemoyne, PA 17043
}

The study area is located in Wood County in northwestern Ohio. Ground water withdrawn for water supply, irrigation, and domestic use accounts for 56 percent of total water use in Wood County. The investigation involves a landfill used for co-disposal of solid and hazardous waste.

The topography in the vicinity of the landfill is nearly featureless; drainage is provided by small ephemeral and perennial streams. The major aquifers are dolomites of Silurian age, which may yicld from 50 to 200 gaiions per minute. The aquifers are confined by 50 to 60 feet of Wisconsinan glacial till, which is overlain by 5 to 10 feet of lacustrine clay. The landfill cells are excavated into the glacial till to a depth of approximately 40 feet.

A ground-water mound beneath the northernmost landfill cells was first noted in March 1984. Subsequent waterlevel measurements confirmed the existence of the mound and helped to define a maximum areal extent of approximately 2 square miles in February 1985. Ground-water levels near the center of the mound fluctuate as much as 14 feet compared to fluctuations of less than 3 feet in wells upgradient of the landfill. Vertical head relations between the landfill, till, and dolomite aquifer indicate that water is flowing downward from the landfill to the dolomite aquifer.

The data suggests that increased recharge or leakage of water to the dolomite aquifer through the landfill and glacial till is the cause of the observed mound. It was expected that some variations in ambient ground-water quality would occur in the wells downgradient of the mound; however, chemical analyses of water collected from 20 wells show only minor differences in physical characteristics, major and minor chemical constituents, and total organic carbon. Analysis for volatile organic compounds did not detect the presence of any constituents above the instrumental detection level. Analysis for base/ neutral and acid-extractable organic compounds detected 2 micrograms per liter of di-n-butylphthalate and 8 micrograms per liter of 2-ethylhexylphthalate in two wells downgradient of the landfill
In an attempt to qualify and further explain water quality and hydrogeologic data, oxygen and hydrogen stableisotope ratios were included in the water-quality investigation. A map of $\delta \mathrm{D}$ and $\delta^{18} \mathrm{O}$ show waters with three different isotopic compositions (in permil relative to Standard Mean Ocean Water) are present in wells tapping the dolomite aquifer upgradient of the landfill. These include the following: an isotopically light water with a $8 \mathrm{D}$ of -77.5 and a $\delta^{18} \mathrm{O}$ of -11.3 ; a heavy water with a $\delta \mathrm{D}$ of -54.5 and a $\delta^{18} \mathrm{O}$ of -8.4 ; and a water with a $\delta \mathrm{D}$ of -72.5 and a $\delta^{18} \mathrm{O}$ of -10.5 that could represent a mixture of the heavy and light waters.

Isotopic compositions of waters from two wells tapping the glacial till at the landfill indicate that heavy water with a $\delta \mathrm{D}$ of -49.5 and $\delta^{18} \mathrm{O}$ of -7.7 is in the till. The isotopic composition of a single sample of a stream receiving surface runoff from precipitation has a $\delta \mathrm{D}$ of -45.0 and a $\delta^{18} \mathrm{O}$ of -7.2 and is the heaviest water sampled. Most waters plot on the local water line, which is defined as: $\delta \mathrm{D}=7.8\left(\delta^{18} \mathrm{O}\right)+10.5$.

Leachates collected from two methane-venting wells have anomalous isotopic content and plot to the left of the local water line.

Several wells in the dolomite aquifer directly downgradient of the landfill have heavy isotopic signatures, indicating that large proportions of till waters are present. Geologic and water-level data indicate that these wells have the greatest potential for showing the effects of increased recharge or leakage from the landfill. Waterquality data from these wells show elevated concentrations of constituents that are indicators of leachateaffected ground waters. Water in a dolomite aquifer well downgradient of the landfill plots to the left of the local water line in the direction of the leachates. The heavier value of $\delta \mathrm{D}$ is considered a preliminary indicator of the presence of landfill leachate in water from this well.

The isotopic data supports the hydrogeologic and chemical -quality data by suggesting that the landfill is affecting ground-water flow and quality in the dolomite aquifer. 


\title{
ESTIMATES OF STREAM LEAKAGE AND HYDRAULIC PROPERTIES OF A GLACIAL AQUIFER NEAR DOVER, NEW JERSEY, BASED ON THE CHEMICAL CHARACTER OF WATER, INCLUDING STABLE ISOTOPES OF HYDROGEN AND OXYGEN
}

\author{
Joel E. Dysart \\ U.S. Geological Survey \\ James T. Foley U.S. Courthouse P.O. Box 1669 \\ Albany, NY 12201
}

Ground water is pumped from three production wells screened in glacial drift at Dover, N.J. Total pumpage from July 1984 through October 1985 averaged 3.6 million gallons per day, and water levels in streambed piezometers in the adjacent Rockaway River indicated infiltration and movement of river water to the production wells . Stable-isotope data for hydrogen and oxygen indicated that water pumped from the production wells was about 30 percent river water and 70 percent water from glacial drift; this suggests a loss from the Rockaway River of about about 1.6 cubic feet per second.

Water samples were collected and measured onsite for temperature, specific conductance, $\mathrm{pH}$, and dissolved oxygen from (1) wells screened in stratified drift in the zone of river infiltration; (2) background wells (those screened in the stratified drift outside the zone of river infiltration); (3) the Rockaway River and associated streambed piezometers; and (4) a bedrock well.

Temporal variations in the (1) isotope values for oxygen18 and deuterium, (2) concentrations of dissolved oxygen, and (3) specific conductance in samples from the river and a streambed piezometer corresponded to changes in river discharge and season. Generally, only small fluctuations of the same constituents were detected in samples from background wells. Many of the changes in chemical character of water from the production wells can be associated with the arrival of river water. For example, the arrival of river water (delta oxygen-18 $=-6.75$ per mil, and specific conductance $=200 \mu \mathrm{S} / \mathrm{cm}$ (microsiemens per centimeter at 25 degrees Celsius) at a production well produced an increase in delta oxygen-18 from -7.75 to 7.45 per mil and a decrease in specific conductance to less than $500 \mu \mathrm{S} / \mathrm{cm}$ for at least 30 days. This suggests that 20 to 30 days are required for this river water to reach the production well.

Frequent measurements of dissolved oxygen and water temperature were made during November 19-21, 1985 in a losing reach of the Rockaway River and a piezometer screened 3 feet below the streambed. Fluctuations of these two characteristics in the river were observed 8 to 24 hours later in the piezometer.

Average horizontal hydraulic conductivity of the stratified drift was 300 to 500 feet per day, and average vertical hydraulic conductivity of the streambed was 1 to 3 feet per day. 


\section{THE USE OF DEUTERIUM AND OXYGEN-I8 TO TRACE THE MOVEMENT OF INDUCED RIVER RECHARGE INTO THE POTOMAC-RARITAN-MAGOTHY AQUIFER SYSTEM, CAMDEN AREA, NEW JERSEY}

\author{
Steven D. McAulcy \\ U.S. Geological Survey \\ Water Resources Division \\ 810 Bear Tavern Road, Suite 206 \\ West Trenton, NJ 08628
}

\author{
Carol Kendall \\ U.S. Geological Survey \\ Water Resources Division \\ 345 Middleficld Road \\ Menlo Park, CA 94025
}

\author{
Thomas V. Fusillo \\ Formerly with U.S. Geological \\ Survey \\ Water Resources Division \\ Reston, VA
}

Withdrawal of ground water for supply in the Camden area of New Jersey has resulted in a reversal of the direction of ground-water flow and has induced the movement of water from the Delaware River into the Potomac-Raritan-Magothy aquifer system. Currently, the regional cone of depression for this system is centered about 5 miles southeast of the river. That part of the regional flow path under examination is located between the river and the center of the cone. Ground-water quality may, thereby, be degraded because of inflow of saline water from the Delaware estuary, movement of the freshwater-saltwater interface from its present position both south and cast of Camden, and the migration of hazardous wastes and landfill leachate into lower aquifers. As part of the effort to evaluate the ground-water resources of the Camden area, the U.S. Geological Survey (USGS), in cooperation with the New Jersey Department Environmental Protection, began in 1983 a study of the use of deuterium and oxygen-18 to trace the movement of river water recharge into the aquifer system.

Deuterium and oxygen-18 can be used as tracers because the isotopic composition of water from the Delaware River is different from that of recharge water infiltrating into the aquifer from the outcrop. From 1983 through 1985, bimonthly samples were collecated from the river and from wells located in lines along the regional flow path. Samples were analyzed by the USGS Isotope Fractionation Project at Reston, Virginia. Values were reported as deltas (ratios of occurrence of less common to more common isotope in the sample to that of ocean water), and in parts per thousand (ppt). Ground-water isotope values were compared to the surface-water isotope values to determine the ratio of ground water to surface water, the amount of seasonal fluctuation, and the lag times of flow from the river to the sampled well.

The delta values for deutcrium and oxygen-18 for river samples near Camden ranged from $-59.0 \mathrm{ppt}$ to $-43.5 \mathrm{ppt}$, and from $-8.90 \mathrm{ppt}$ to $-6.70 \mathrm{ppt}$, respectively. The range of values for ground water near the river does not differ from those of surface water, but the occurrence of scasonal isotopic fluctuations in surface water permits tracing of the surface water into the aquifer system . Ground water within one mile of the river was found to have isotopic compositions that are indicative of the presence of more than 75 percent river water. Nonuniform ground-water flow paths and variations in isotopic composition of recharge waters of different ages hinders determination of the percentage of river water present at some locations. 


\title{
USE OF REGRESSION ANALYSIS AND TIME SERIES METHODS FOR ESTIMATING CHEMICAL LOADS FOR TWO HYDROLOGICALLY DISSIMILAR STREAMS
}

\author{
Rochelle Rittmaster \\ Formerly with U.S. Geological Survey \\ Water Resources Division \\ Marlborough, MA
}

\begin{abstract}
Concern about the effects of acidic deposition-"acid rain" - on water quality in New England led to a study of the chemical quality and hydrology of two streams which discharge to the Quabbin Reservoir, the major drinkingwater supply for Boston. Characteristic of lowalkalinity streams in the central highlands of Massachusetts, the Swift River and Fever Brook drain glaciated noncarbonate-bearing crystalline terrane. Whereas the Swift River has steeply graded headwater areas and minor impoundments, Fever Brook is gently graded and flows through two impoundments and some swampy areas.
\end{abstract}

An objective of the study is to compare chemical inputs and outputs for each watershed. Inputs are calculated with chemical analyses of weekly composite wet deposition and corresponding precipitation volume based on daily measurements. Regression analysis was planned to quantify relations between instantaneous discharge and constituent concentrations in each stream. Chemical outputs would then be calculated with mean daily discharge values and constituent concentrations estimated from the various regression equations. However, preliminary analysis indicates only partial success with the regression approach.

There were significant $\left(\mathrm{R}^{2}\right.$ greater than 0.70$)$ correlations between discharge and alkalinity, dissolved silica, and major cation concentrations in Swift River. In contrast, only alkalinity significantly correlated with discharge for Fever Brook. Poor correlations $\left(\mathrm{R}^{2}\right.$ less than 0.50 ) between discharge and nitrate, sulfate, and chloride were found for both streams. Alternatively, stream loads for constituents that do not demonstrate strong relations to discharge will be calculated using discrete weekly measurements of concentration and corresponding weekly discharge.

To enhance understanding of the processes affecting water quality, regression equations and correlation coefficients will be compared to geologic and hydrologic characteristics of each watershed, net chemical outputs, and concentration relationships among species in the stream waters. In addition to good correlations to Swift River discharge ( $R^{2}$ specific conductance 0.80 , hydrogen ion 0.85 , calcium 0.85 , magnesium 0.77 , sodium 0.70 ), there were significant relations among calcium, magnesium, and alkalinity. Lack of similar correlations in Fever Brook may be attributable to impoundments that dampen flow response and increase retention time of waters in the basin. Poor correlations between discharge and the anions nitrate, sulfate, and chloride may reflect (1) variable inputs of these constituents from precipitation and road salt, and (2) biological cycling of sulfur and nitrogen in the watersheds.

\section{STREAM CHEMISTRY RESPONSE DURING EPISODES OF ACIDIC RAINFALL AND SNOWMELT RUNOFF ON LAUREL HILL, SOMERSET COUNTY, PENNSYLVANIA, NOVEMBER 1983 TO JULY 1985}

\author{
E. C. Witt, II \\ U.S. Geological Survey \\ Water Resources Division \\ 840 Market Street \\ Lemoyne, Pennsylvania 17043
}

\author{
J. L. Barker \\ Formerly with U.S. Geological Survey \\ Water Resources Division \\ Pittssburgh, PA
}

Quantitative data on changes in stream-water quality during and after individual storms and snowmelts are needed to understand the response of streams to atmospheric deposition during different seasons and stream- flow conditions. An intensive study of stream water and atmospheric-deposition chemistry was conducted on the South Fork Bens Creek (drainage area $=3.28 \mathrm{mi}^{2}$ ) and North Fork Bens Creek (drainage area. $=3.45 \mathrm{mi}^{2}$ ) drainage basins. 
Stream-chemistry response and recovery of storms and snowmelt depends on the hydrologic status of the basin, magnitude of the runoff, and the alkaline potential of the unconsolidated zone. Summer thunderstorms with characteristically short periods of intense rainfall and rapid runoff appear to have minimal effect upon stream quality; water quality returns to pre-episode concentrations about the same time discharge recovers to pre-episode conditions. Frontal weather systems that generally produce higher volumes of precipitation over longer periods of time and retain large volumes of precipitation within the unconsolidated zone result in a greater response in stream quality. Recovery to precpisode conditions is measured in days following recovery of discharge to base flow. Snowmelt produces a severe depression in $\mathrm{pH}$. Concentrations of dissolved aluminum, nitrate, and manganese are increased for about 1 week after stream discharges return to normal.

Samples collected during 12 storm runoffs and snowmelts show that concentrations of dissolved sulfate, aluminum, iron, and manganese are directly related to streamflow; concentrations of dissolved chloride, sodium, and $\mathrm{pH}$, however, are inversely related to streamflow. Wet deposition samples contained from 40 to 50 percent sulfate ions and only 3 to 8 percent nitrate ions throughout the study. This suggests that sulfuric acid is the primary component responsible for acidified rain. Correlation between $\mathrm{pH}$ and nitrate reveals nitric acid to be a significant contributor to stream acidity during snowmelt runoff.

\section{STREAM ACIDIFICATION IN THE CATSKILL MOUNTAINS OF NEW YORK}

Peter S. Murdoch

U.S. Gcological Survey

Water Resources Division

U.S. Courthouse P.O. Box 1669

Albany, NY 12201
Charles R. Barnes

Formerly with U.S. Geological Survey

Water Resources Division

Albany, NY
Stream chemistry response and recovery of storms and snowmelt depend on the hydrologic status of the basin. Fifty streams in the headwaters of the six New York City rescrvoirs in the Catskill Mountains are being monitored at least four times annually for stage and water chemistry to assess possible effects of acid deposition. Six streams, selected to represent a range of alkalinity, are being monitored for discharge and stream chemistry nine times per year at varied flows. Biscuit Brook near Claryville, New York is being monitored for continuous discharge, weckly precipitation, and both event and weckly stream chemistry.

Areal sulfate wet deposition during 1985, was approximately 31 kilograms per hectare per year [(kg/ha)/yr]. If 30 percent of total sulfate contribution is by dryfall, sulfate load to the Biscuit Brook basin equaled output during water year 1985, with an average stream concentration of 135 microequivalents per liter $(\mu \mathrm{eq} / \mathrm{L})$. Sulfate concentrations appear nearly uniform in Catskill streams for most flow ranges $(140 \mu \mathrm{eq} / \mathrm{L})$, with only slight variability when flows are below 6 liters per second per square kilometer [(L/s)/km2].

Differences in $\mathrm{pH}$ and alkalinity among streams are controlled by the supply of base cations. Variability in the percentage of calcium carbonate in till deposits is a primary factor in the variability of stream chemistry. During low flow, mean base cation concentrations for the six New York City reservoir watersheds ranged from 168 to $700 \mu \mathrm{eq} / \mathrm{L}$. The cation denudation rate for Biscuit Brook averaged $34(\mathrm{~kg} / \mathrm{ha}) / \mathrm{yr}$ as $\mathrm{Ca}+$, and the average base cation concentration was $225 \mu \mathrm{e} / \mathrm{L}$. Preliminary data indicate 48 percent of the streams in this region are either only slightly sensitive or insensitive to acidification (greater than $200 \mu \mathrm{eq} / \mathrm{L}$ of alkalinity during low flow), 30 percent are sensitive ( 40 to $200 \mu \mathrm{eq} / \mathrm{L}$ ), 15 percent are extremely sensitive $(0$ to $40 \mu \mathrm{eg} / \mathrm{L})$, and 7 percent are acidified (less than $0 \mu \mathrm{eq} / \mathrm{L}$ ). Replacement of bicarbonate by sulfate results in alkalinities approximately 125 to $150 \mu \mathrm{eq} / \mathrm{L}$ less than indicated by calcium and magnesium concentrations.

On the basis of Henriksen's empirical relation between $\mathrm{pH}$ and calcium, some degree of acidification is apparent in all streams where the calcium concentration is less than $200 \mu \mathrm{eq} / \mathrm{L}$. Measured stream $\mathrm{pH}$ values are similar to those predicted from either stream sulfate concentrations or precipitation $\mathrm{pH}$ using Henriksen's nomograph. Increased levels of acidic cations $(\mathrm{H}+$ and $\mathrm{A} 1+3)$ occur in streams whenever strong acid (sulfate plus nitrate) inputs exceed 70 percent of base cation outputs. 
Base-cation concentrations decrease faster than anions during high-flow conditions, depressing alkalinity and pH. At all sensitive streams, alkalinity approaches zero when flow exceeds $250(\mathrm{~L} / \mathrm{s}) / \mathrm{km}^{2}$. Storms at Biscuit Brook indicate little or no change in base cation, sulfate, or chloride concentrations until flow exceeds $250(\mathrm{~L} / \mathrm{s}) / \mathrm{km}^{2}$ Nitrate is a major contributor to stream acidity in the spring and late fall at all flows but is insignificant during summer. Baseflow stream $\mathrm{pH}$ at Biscuit Brook was 6.3 during water year 1985, but in three out of nine storms studied, $\mathrm{pH}$ decreased to less than 5.0. The comparison of results from Biscuit Brook to other Catskill streams suggest episodic acidification occurs in approximately half the streams in the Catskill region.

\section{SENSITIVITY OF STREAM BASINS IN SHENANDOAH NATIONAL PARK TO ACID DEPOSITION}

\author{
Dennis D. Lynch \\ U.S. Geological Survey \\ Water Resources Division \\ 10615 S.E. Cherry Blossom Drive \\ Portland, OR 97216
}

\author{
Nancy B. Dise \\ University of Virginia \\ Richmond, VA 23230
}

Six synoptic surveys of 56 streams that drain Shenandoah National Park, Virginia, were conducted in cooperation with the University of Virginia to evaluate sensitivity of dilute headwater streams to acid deposition and to determine the degree of acidification of drainage basins. Stream samples were collected between August 1981 and June 1982; each sample was analyzed for alkalinity, major anions and cations, silica, and $\mathrm{pH}$.

Flow-weighted alkalinity concentrations of most streams are less than $200 \mu \mathrm{eq} / \mathrm{L}$ (microequivalents per liter), which is commonly considered the threshold of sensitivity. Stream-water sensitivity is strongly affected by drainage-basin bedrock type. Streams draining the resistant siliceous bedrocks show extreme sensitivity (alkalinity less than $20 \mu \mathrm{eq} / \mathrm{L}$ ); streams draining granite and granodiorite show a high degree of sensitivity (20 to $100 \mu \mathrm{eq} / \mathrm{L}$ ); and streams draining the metamorphosed volcanics show moderate to marginal sensitivity (101 to $200 \mu \mathrm{eq} / \mathrm{L})$.

The relation between bedrock type and stream-water chemistry in the Park was evaluated by multipleregression analysis. Results from this analysis indicate that stream-water concentrations of alkalinity, silica, and base cations are strongly related to bedrock type and that sulfate concentrations are strongly related to geographic location in the Park. The regression equation for alkalinity is shown to be a useful tool for predicting sensitivity of unsampled streams within the Park and for streams outside the Park which drain the same geologic formations. Predicted concentrations of alkalinity are generally within $30 \mu \mathrm{eq} / \mathrm{L}$ of measured concentrations.

A comparison of stream-water chemistry to that predicted by a model based on carbonic-acid weathering reactions suggests that all basins in the Park show signs of acidification by atmospheric deposition. Acidification is defined as a neutralization of stream-water alkalinity and/ or an increase in the base-cation weathering rate. These processes cannot be distinguished with the available data, but both are detrimental to stream basins in the Park. Acidification averages $50 \mu \mathrm{eq} / \mathrm{L}$, which is fairly evenly distributed in the Park. However, the effects of acidification are most strongly felt in extremely sensitive basins, such as those underlain by the Antietam Formation, which have stream-water $\mathrm{pH}$ that averages 4.99 and mineral acidity of $7 \mu \mathrm{eq} / \mathrm{L}$. Acidification of basins in the other geologic formations also may be significant, but higher "preacidification" concentrations of stream-water alkalinity and base cations make it less apparent. 


\title{
DUAL-ACIDITY-TITRATION CURVES-FINGERPRINT, INDICATOR OF REDOX STATE, AND ESTIMATOR OF IRON AND ALUMINUM CONTENT OF ACID- MINE DISCHARGE AND RELATED WATERS
}

\author{
Arthur N. Ott \\ Formerly with U.S. Geological Survey \\ Water Resources Division \\ Lemoyne, PA
}

Titration curves constructed from data obtained from the determination of acidities for raw and oxidized samples of acid mine drainage can be used to estimate a sample's redox state as well as its dissolved ferrous iron, ferric iron, and aluminum content. A nonlinear regression equation with a correlation coefficient of 0.98 was determined for the relation between the titratable acidity to $\mathrm{pH} 4.0$ and the concentration of oxidized iron. A linear-regression equation with a correlation coefficient of
0.99 was derived for the relation between the titratable acidity for the hydrogen peroxide treated sample from $\mathrm{pH}$ 4.0 to 5.0 and the concentration of aluminum, The dualtitration curves constitute a characteristic shape or "fingerprint" for acid-mine drainage that should not change - except to contract or elongate, depending on sample dilution-unless a geochemical change occurs to alter the metal proportions.

\section{THEORETICAL TECHNIQUE FOR DETERMINING THE CUMULATIVE IMPACT OF IRON AND MANGANESE OXIDATION IN STREAMS RECEIVING DISCHARGE FROM COAL MINES}

\author{
By Keith E. Bobay, \\ U.S. Geological Survey \\ Water Resources Division, \\ 5957 Lakeside Boulcvard \\ Indianapolis, IN 46278
}

Two U.S. Geological Survey computer programs are modified and linked to predict the cumulative impact of iron and manganese oxidation in coal-mine discharge water on the dissolved-chemical quality of a receiving stream. The coupled programs calculate the changes in dissolved-iron, dissolved-manganese, and dissolvedoxygen concentrations, alkalinity, and $\mathrm{pH}$ of surface water downstream from the point of discharge. First, the one-dimensional, steady-state streamwater-quality program uses a dissolved-oxygen model to calculate the changes in concentration of elements as a function of the chemical reaction rates and time of travel. Second, a program combining $\mathrm{pH}$, reduction-oxidation potential, and equilibrium equations (PHREEQE) uses an aqueous ion association model to determine the saturation indices and to calculate $\mathrm{pH}$ and alkalinity; it then mixes the discharge with a receiving stream. The kinetic processes of the first program dominate the system, whereas the equilibrium thermodynamics of the second define the limits of the reactions.

The water-quality program calculates the dissolvedconstituent concentrations at fixed intervals along a stream or discharge channel. A modified Streeter-Phelps equation is used to calculate the new dissolved-oxygen concentration from the initial concentration and from oxygen sources and sinks. The equation is modified to treat atmospheric reaeration as the only source of oxygen through the reach; the oxidation of ferrous and manganous ions, calculated as pseudo first-order reactions, are the only sinks. PHREEQE models the removal of oxygen, iron, and manganese from solution as the metals are oxidized and precipitate to the stream bottom. The final $\mathrm{pH}$ and $\mathrm{pE}$, new concentrations, the distribution of aqueous species, and the saturation state of the aqueous phases are calculated in PHREEQE. Finally, the discharge is mixed with a receiving stream, and the calculations are repeated with the new solution.

A comprehensive test of the technique was not possible because a complete set of data was unavailable. However, the cumulative impact of representative discharges from several coal mines on stream quality in a small watershed in southwestern Indiana was simulated to illustrate the operation of the technique and to determine its sensitivity to changes in physical, chemical, and 
kinetic factors. Discharges averaged 2 cubic feet per second, with a pH of 6.0 , and concentrations of $7.0 \mathrm{mg} / \mathrm{L}$ dissolved iron, $4.0 \mathrm{mg} / \mathrm{L}$ dissolved manganese, and $8.08 \mathrm{mg} / \mathrm{L}$ dissolved oxygen . Results of the simulations indicated the following cumulative impact on the receiving stream from five discharges as compared with the impact from one discharge: 0.30 unit decrease in $\mathrm{pH}$, $1.82 \mathrm{mg} / \mathrm{L}$ increase in dissolved-iron, $1.50 \mathrm{mg} / \mathrm{L}$ increase in dissolved-manganese, and $0.24 \mathrm{mg} / \mathrm{L}$ decrease in dissolved-oxygen concentration.

\section{FACTORS AFFECTING ACIDIC GROUND-WATER CONTAMINATION AT A SURFACE COAL MINE IN WESTERN PENNSYLVANIA}

\author{
John $\mathrm{H}$. Williams \\ U.S. Geological Survey \\ Water Resources Division \\ James T. Foley U.S. Courthouse P.O. Box 1669 \\ Albany, NY 12201
}

The geohydrologic and geochemical factors affecting the spatial and temporal distribution of acidic, ground-water contamination at a reclaimed, surface mine in the bituminous coal fields of western Pennsylvania were studied. The investigation was completed as part of an acid-minedrainage abatement project in cooperation with the Pennsylvania Bureau of Mining and Reclamation and the Pennsylvania State University. As the result of the weathering of pyrite and clay minerals in the backfilled spoil, the ground water at the mine site is highly acidic (pH 2 to 4.5 ) and contains up to $5,300,1,200$, and 310 milligrams per liter dissolved sulfate, iron, and aluminum, respectively. The mine spoil ranges from 0 to 70 feet thick and consists of noncalcareous sandstone, silt-stone, and shale fragments. Some of the fine-grained spoil is pyritic, including coal-preparation wastes that contain up to 5 percent pyrite.

The acidic reactions involving the dissolution and oxidation of pyrite produce two moles of sulfate and one mole of ferrous iron per mole of weathered pyrite, which results in a sulfate to iron ratio, in milligrams per liter, of 3.4:1. Ground-water samples collected from pyritic spoil have a pH ranging from 3 to 4.5 and dissolved sulfate to iron ratios of 3.5:1 to 4.5:1 with nearly all of the dissolved iron present in the ferrous state. As the acidic water flows through nonpyritic spoil, the ferrous iron oxidizes to ferric iron, which precipitates, producing a pH of 2 to 3 and sulfate to iron ratios of 5.9:1 to $72: 1$.

At a pH of less than 5, aluminum is released from clay minerals by dissolution and cation exchange. The ratio of dissolved iron to aluminum in acidic water decreases along the flow path in nonpyritic spoil as ferric iron precipitates and additional aluminum is dissolved. Samples of acidic water that had flowed through non-pyritic spoil were found to have dissolved iron to aluminum ratios of $0.16: 1$ to $1.9: 1$ compared to $11: 1$ to $110: 1$ for

\author{
Kenn L. Pattison \\ Formerly with U.S. Geological Survey \\ Water Resources Division \\ Albany, NY
}

samples collected from pyritic spoil. Acidic-contaminant concentrations in the ground water increase as much as 30 times following major storms that are preceded by an extended dry period. The probable immediate source of increased contamination is metallic salts produced by pyrite oxidation and clay mineral dissolution that are stored in the unsaturated zone during times of low precipitation and recharge; and, subsequently, are flushed by infiltrating water during storms.

Acidic seepage is present in two major areas-at the toe of the mine spoil and on the hillside downgradient of the mine. The average ground-water discharge at each seepage area is approximately 30 gallons per minute. As a result of the large contrast in permeability between the mine spoil and coal underclay, the configuration of the mine floor significantly affects ground-water flow. Acidic seepage from the mine spoil occurs where the lowest part of the mine floor intersects the toe of the spoil. Where the underclay has been fractured or removed during mining, acidic water leaks downward through the mine floor to underlying bedrock aquifers. The hydraulic gradient between the mine-spoil and bedrock aquifers is about 0.5 foot of head loss per vertical foot of aquifer. Acidic water discharges from the bedrock aquifers on the hillside downgradient of the mine approximately 1,000 feet from the toe of the spoil and 60 feet below the mine floor.

Surface runoff during and following storms causes significant dilution of acidic contamination at the hillside seepage area. Variability in total discharge at the scepage area explains 67 to 97 percent of the variation in contaminant concentrations. At a drain constructed to intercept the acidic seepage at the toe of mine spoil, contaminant concentrations are relatively constant; thus, contamination loads increase directly with increasing discharge. 


\title{
PREIMPOUNDMENT WATER QUALITY OF SWATARA CREEK, PENNSYLVANIA
}

\author{
David K. Fishel \\ U.S. Geological Survey \\ Water Resources Division \\ 840 Markct Street \\ Lemoync, PA 17043
}

The water quality of Swatara Creck was studied from July 1981 through September 1984 in cooperation with the Pennsylvania Department of Environmental Resources, Burcau of State Parks in order to determine the impact of coal mining activitics on the water quality of a planned 10,50--acre-foot rescrvoir. The impoundment is to be used for recreation and water supply for the city of Lcbanon and surrounding communitics. Anthracite was extensively mined in a $72.6 \mathrm{mi}^{2}$ subbasin within the $167-\mathrm{mi}^{2}$ study area upstream from the proposed dam site. The project was designed to (a) measure surfacewater inflows and outflow in the planned impoundment area, and measure concentrations of suspended sediment, nutrients, and constituents common to acid mine drainage in these flows, (b) determine discharges of the above constituents to the planned reservoir during a year of average streamflow, (c) detcrmine nutrient and metal concentrations in bottom material in the vicinity of the impoundment, and (d) cstimate the future water quality in and downstream from the planned reservoir.

Inflows to and outflow from the study area are poorly buffered. Median alkalinity and acidity concentrations were less than $10 \mathrm{mg} / \mathrm{L}$ and $5 \mathrm{mg} / \mathrm{L}$ as $\mathrm{CaCO}_{3}$, respectivcly. Maximum total iron, aluminum, and manganesc concentrations of $100,000 \mu \mathrm{g} / \mathrm{L}$ (micrograms per liter), $66,000 \mu \mathrm{g} / \mathrm{L}$, and $2,300 \mu \mathrm{g} / \mathrm{L}$, respectively, in storm runoff indicate that mine drainage is discharged into Swatara Creck above the proposed impoundment. Storm runoff concentrations for suspended metals and phosphorus are directly related to suspended-sediment concentrations. Regression equations from these relations were used to calculate storm discharges.

The sum of the storm-flow and base-flow discharges indicates that more than 692,300 , and 94 tons of total recoverable iron, aluminum, and manganese, respectively, were discharged in the area of the planned impoundment during a year of nearly normal streamflow. Most of the annual storm discharge occurs in 4 to 5 days.

In addition to mine drainage, point-source nutrient and metal discharges will probably impact the planned impoundment. Concentrations of total recoverable aluminum, chemical-oxygen demand, total recoverable lead, ats dissolved phosphorus, measured just below a point discharge, after mixing with Swatara Creek, were $35,300 \mu \mathrm{g} / \mathrm{L}, 290 \mathrm{mg} / \mathrm{L}$ (milligrams per liter), $32 \mu \mathrm{g} / \mathrm{L}$, and $14 \mathrm{mg} / \mathrm{L}$, respectively. Point-source discharges are probably at least partly responsible for the poor correlations among base-flow nutrient, metal concentrations, and streamflow in Swatara Creek.

Bottom-material concentrations of aluminum, iron, lead, copper, and zinc reached a maximum just downstream from the point-source discharge. Analyses of washings from the base of a 529,000-ton culm pile that is expected to take up to three years to remove and will become a peninsula in the planned reservoir indicate that the fine coal particles and runoff from the waste pile contain elevated concentrations of aluminum, iron, copper, lead, mercury, and selenium, which may be discharged to the reservoir,

Measured nutrient concentrations in inflow and estimates of phosphorus loadings indicate the planned lake will support aquatic life and may become eutrophic if phosphorus discharges are not reduced. Unless releases from the planned Swatara Creek reservoir are carefully controlled, discharges with poorly oxygenated water and elevated metal concentrations may degrade the downstream water quality and be detrimental to the aquatic community. 
oxygen demand $\left(0_{2}\right)$ ranged from 0.4 to 6.0 and 0.0 to 4.9 grams $0_{2}$ per square meter per day for the tidal river and estuary, respectively.

The variability reflected the influence, but lack of clear dominance, of many interacting factors, including sediment-nutrient concentrations, sediment grain size, water temperature, oxygen availability, benthic macroand microorganism populations, and mctcorologic conditions. As a result, the year-to-year variation at individual stations commonly exceeded longitudinal or scasonal variation.
The data were grouped by location in either the tidal river or the estuary. The freshwater and estuarine sediments generally were a source of ammonium and a sink for nitrite plus nitrate. The fresh-water sediments were predominantly a sink for dissolved reactive phosphorus, whereas the estuarine sediments were predominantly a source. Again, both environments were intermittently sources and sinks for a given nutrient. Seasonal variation in sediment-oxygen demands was observed at some stations, but those rates were highly variable, preventing generalization of the results.

\title{
GROUND-WATER QUALITY AS RELATED TO HOUSING DENSITY, CAPE COD, MASSACHUSETTS
}

\author{
Jamis H. Persky \\ F ormerly with U.S. Geological Survey \\ Water Resources Division \\ Marlborough, MA
}

Correlation of median nitrate concentration in ground water with housing density in 18 sample areas on Cape Cod yields a Pcarson correlation coefficient of 0.802 , which is significant at the 95-percent confidence level. Where housing density is greater than one unit per acre, five of nine sample areas have nitrate concentrations greater than 5 milligrams of nitrogen per liter in 25 percent of the wells. On the other hand, where housing density is less than one unit per acre, one of nine sample areas have nitrate concentrations greater than 5 milligrams of nitrogen per liter in 25 percent of the wells. Five milligrams of nitrogen per liter is the Barnstable County planning goal for nitratc. Median concentrations of sodium and iron, and median levels of $\mathrm{pH}$ and specific conductance, are not significantly correlated with housing density.
A computer-generated map of nitrate distribution shows a positive relation between nitrate concentration and housing density on Cape Cod. However, the presence of septage- or sewage-disposal sites and fertilizer use also are important factors that affect nitrate concentration. A map of specific conductance also shows a positive relation to housing density, but little or no relation between housing density and sodium, ammonia, $\mathrm{pH}$, or iron is apparent on the maps.

Chemical analyses of samples collected from 3,468 private- and public-supply wells between January 1980 and June 1984 were used to examine the extent to which housing density determines water quality on Cape Cod-a sole-source aquifer with few sewered areas. As of December 1985, the water-quality data base maintained for Cape Cod had increased to approximately 5,500 analyses from 4,500 wells. 


\section{EVIDENCE FOR LEACHING OF TRACE-METALS FROM PLUMBING MATERIALS EXPOSED TO ACIDIC GROUND WATER IN SELECTED AREAS OF THE NEW JERSEY COASTAL PLAIN}

\author{
George R. Kish \\ Formerly with U.S. Geological Survey \\ Water Resources Division \\ West Trenton, NJ
}

\author{
Jo Ann Macy \\ U.S. Geological Survey \\ Water Resources Division \\ 5957 Lakeside Boulevard \\ Indianapolis, IN 46278
}

In 1981, widespread lead contamination of domestic wells in Beachwood Borough and Berkeley Township, Ocean County, N.J., was documented by the Ocean County Health Department. As part of a study to determine regional sources of environmental lead in shallow ground water, the U.S. Geological Survey sampled tap water from domestic wells in newly constructed homes in Galloway Township, Atlantic County, and Beachwood Borough and Berkeley Township. Ground water in these areas is acidic with low hardness and low alkalinity and is corrosive. In order to determine if trace metals were leaching from plumbing materials, standing and running tap water was sampled. The potable-water distribution systems in all of the homes sampled are constructed primarily of copper with lead-based solder joints. Inhouse water treatment is used in Berkeley Township but not in Galloway Township.

In Berkeley Township, 6 of the 11 samples exceeded the U.S. Environmental Protection Agency's (USEPA) Maximum Contaminant Level (MCL) for lead $(50 \mu \mathrm{g} / \mathrm{L})$ and the USEPA Secondary Maximum Contaminant level (SMCL) for copper $(1,000 \mu \mathrm{g} / \mathrm{L})$. In Beachwood
Borough, 2 of the 7 samples exceeded the MCL for lead. In Galloway Township, three sets of samples were collected at 14 homes. In the first sample set, collected after the water had been standing in the pipes overnight, 12 of 14 samples exceeded the MCL for lead and 13 of 14 exceeded the SMCL for copper. In the second sample set, collected after the water had been running for 2 to 3 minutes and a noticeable (to the touch) temperature change was detected; 2 of the 14 samples exceeded the MCL for lead; and 9 of 14 exceeded the SMCL for copper. In the third sample set, collected after the water had been running an additional 15 minutes, none of the samples exceeded the MCL for lead or the SMCL for copper.

Significant amounts of lead and copper are being leached from household plumbing systems into tap water from the homes sampled in Berkeley and Galloway Townships. Increased residence time of soft, acidic ground water in new home-plumbing systems caused increascd tracemetal concentrations in drinking water. Available data suggest that plumbing system age and in-house treatment systems may affect trace-metal concentrations in drinking water.

\section{SEDIMENT-NUTRIENT DYNAMICS AND SEDIMENT-OXYGEN DEMAND IN THE TIDAL PATUXENT RIVER AND ESTUARY, MARYLAND}

\author{
Bruce M. Lantrip \\ Formerly with U.S. Geological Survey \\ Water Resources Division \\ Towson, MD
}

\author{
Robert M. Summers \\ U.S. Geological Survey \\ Water Resources Division \\ 208 Carroll Building \\ 8600 LaSalle Road \\ Towson, Md 21204
}

A 2-year intensive study of the sediment-nutrient dynamics of a subestuary of the Chesapeake Bay was conducted using benthic respirometers at 11 stations on each of 8 cruises to measure in situ nutrient fluxes of nitrogen $(N)$ and phosphorus $(\mathrm{P})$ and sediment-oxygen $\left(\mathrm{O}_{2}\right)$ demands. Rate estimates of $N, 0$, and $P$ fluxes were highly variable.
The following ranges of flux rates (as micromoles per square meter per hour as $\mathrm{N}$ or $\mathrm{P}$ ) were observed in the tidal river and estuary, respectively: -300 to 1,900 and - 400 to 3,000 as $\mathrm{N}$ for ammonium; $-3,900$ to 3,400 and $-1,300$ to 2,600 for nitrite plus nitrate; -170 to 190 and -20 to 700 for dissolved reactive phosphorus. Sediment- 


\section{PRELIMINARY STUDY OF THE RELATION BETWEEN LAND USE AND GROUND-WATER QUALITY OF THE UPPER GLACIAL AQUIFER IN NASSAU AND SUFFOLK COUNTIES, LONG ISLAND, NEW YORK}

\author{
David A. Eckhardt, \\ U.S. Geological Survey \\ Water Resources Division \\ 521 West Seneca Street \\ Ithaca, NY 14850
}

\author{
Edward T. Oaksford \\ U.S. Geological Survey \\ Water Resources Division \\ 227 N. Bronough Street \\ Tallahassee, FL 32301
}

\author{
W. Flipse, Jr., \\ Formerly with U.S. Geological Survey \\ Water Resources Division \\ Ithaca, NY
}

The chemical quality of ground water in the upper glacial (water-table) aquifer beneath differing land-use areas of Nassau and Suffolk Counties was examined to evaluate the impact of human activities on ground water. The upper glacial aquifer consists of unconsolidated Pleistocene deposits of primarily sand and gravel; it overlies Cretaceous deposits, which form the bulk of the island's aquifer system. The aquifer system is the sole source of drinking water for more than 3 million people in the twocounty area, but contamination has restricted the use of the upper glacial aquifer for public-water supply in developed areas; thus, it is used mainly in rural areas of Suffolk County.

Water-quality data were selected from nearly 14,000 chemical analyses made by Federal, State, and county agencies during 1978-85 on samples from 903 wells in the two-county area. Land-use categories were those used in a 1981 survey by the Long Island Regional Planning Board, including industrial, commercial, transportation, agricultural, institutional, recreational, and undeveloped areas, and three different densities of residential areas. Parametric and nonparametric statistical procedures were used to evaluate the relation between ground-water quality and the predominant land use within a half-mile radius of sampled wells.

The highest median chloride and total dissolved-solids concentrations were found in wells in high-density residential areas (more than 5 units per acre), and the highest median nitrate, sulfate, and calcium concentrations were found in wells in agricultural and high-density inorganic chemical constituents were found in wells in undeveloped and low-density residential areas (1 or fewcr units per acre); volatile organic compounds were infrequently detected in these same arcas.

The most commonly detected volatile organic compounds were 1,1,1-trichloroethane ( 24 percent of wells), tetrachloroethylene (20 percent), trichlorocthylene, (18 percent), chloroform ( 9 percent), and 1,2-dichlorocthylene ( 5 percent). The highest concentrations and most frequent detection of volatile organic compounds were in wells in industrial and commercial areas. The compounds were also detected frequently in wells in high-density residential, institutional, and transportation arcas. The spatial distributions of trichlorocthylene, chloroform, and other volatile organic compounds in the upper glacial aquifer are directly correlated with population density in the two-county area . Carbofuran, a carbamate insecticide, was detected in 42 percent of wells in agricultural areas, whereas heptachlor epoxide, a chlorinated-hydrocarbon insecticide, was detected in 20 percent of wells in high-density residential areas.

Median concentrations of total dissolved solids and detection frequencies of tetrachloroethylene, trichloroethylene, and 1,1,1-trichloroethane were higher in sewered areas than in unsewered areas. Several factors may account for this, including (1) concentration of commerce and industry in sewered areas, which are sources of leaks and spills of these contaminants, and (2) leakage from sewers. Also, some contaminants that were present in areas before sewer installation may persist in the aquifer system. 


\section{PRELIMINARY ASSESSMENT OF WATER QUALITY AND ITS RELATION TO HYDROGEOLOGY AND LAND USE: POTOMAC-RARITAN-MAGOTHY AQUIFER SYSTEM, CENTRAL NEW JERSEY}

\author{
Eric F. Vowinkel and John Nawyn \\ U.S. Geological Survey \\ 810 Bear Tavern Road, Suite 206 \\ West Trenton, NJ 08628
}

\author{
Cynthia Barton \\ U.S. Geological Survey \\ 840 Market Street \\ Lemoyne, PA 17043
}

The relation of water quality to hydrogeology and land use in the Potomac-Raritan-Magothy aquifer system in central New Jersey was evaluated using the KruskalWallis test and frequency-of-detection method. Field and lab measurements of chemical characteristics and concentrations of major ions, nutrients, trace metals, phenols, purgeable organic compounds ( $\mathrm{POC}$ ), and pesticides from 71 wells, screened in or near the recharge area of the upper and middle aquifer, were compared by hydrogeologic factors and land-use groups.

Major-ion concentrations are similar in the two aquifers . However, concentrations of metals, dissolved organic carbon (DOC), phenols, and ammonia are higher in the upper aquifer. Field characteristics and concentrations of major ions, trace metals, and nutrients did not differ between unconfined and confined parts of the aquifer system. DOC, phenol, and POC concentrations are higher in the unconfined parts of the aquifer system.

The study area was classified into three land-use groups: undeveloped, agricultural, and urban. Two methods were used to classify the land use at a sampled well. Method I used the land use with the greatest percent within a quarter-mile radius of the well. Method II used a presence-absence procedure based on a quarter-mile radius from the well.

In undeveloped areas, water quality primarily is influenced by the wetlands land-cover. Both Methods I and II show that concentrations of cobalt, iron, and zinc are highest and concentrations of dissolved oxygen and nitrate are lowest in undeveloped areas. In addition, Method I shows that concentrations of magnesium and chromium are lowest and concentrations of aluminum and beryllium are highest in undeveloped areas. In agricultural areas, concentrations of major ions and trace metals are

lower thai in undeveloped and urban areas. Both Methods I and II indicate that concentrations of aluminum, iron, and cobalt are lowest in agricultural areas. Using Method II, chloride, sulfate, and sodium concentrations are lowest in agricultural areas, and concentrations of dissolved oxygen, copper, nitrate, and total pesticides are highest. In urban areas, few constituent concentrations differ from that in waters of other areas using either land-use method, probably because of the history of development. Many urban areas are located on or near undeveloped wetlands, and residential land has replaced much of the agricultural land. Method I shows that concentrations of dissolved oxygen, magnesium, barium, and nitrate are highest in urban areas. POC and orthophosphate are most frequently detected in urban areas using both methods.

Significant differences in water quality among land-use groups classified by both methods were determined. Method I is better suited for characterizing the water quality of a land-use group because the effects of other land uses are minimized. Method II is better at identifying contamination resulting from human activity because the method considers all neighboring land uses even though they may not constitute the greatest percentage of land within a quarter-mile of the well. 


\title{
CHEMISTRY OF WATER IN AN UNCONFINED AQUIFER UNDER AN IRRIGATED FIELD IN EASTERN SUSSEX COUNTY, DELAWARE
}

\author{
Judith M. Denver \\ U.S. Geological Survey \\ Water Resources Division \\ $300 \mathrm{~S}$. New Street \\ Federal Building \\ Dover, DE 19901
}

\begin{abstract}
Chemical analyses of ground-water samples and water levels from piezometers with screened intervals at various depths around a 220-acre field are being used to study the subsurface distribution and movement of nitrate and other fertilizer components. The piezometer network is focused around a centrally-located well screened over the bottom third of the unconfined aquifer (from 60 to 90 feet below land surface) that supplies about 1,100 gallons per minute to a center-pivot irrigation system. The aquifer consists mainly of permeable sand and gravel; its shallow water table is susceptible to contamination by nitrate and other chemical constituents associated with agricultural applications of inorganic fertilizers, manure, and lime.
\end{abstract}

Field measurements of specific conductance, $\mathrm{pH}$, alkalinity, dissolved oxygen, chloride, and water temperature were made at each piezometer in May and July 1985, and in January 1986. Six of the piezometers also were sampled in October 1985 for laboratory analysis of major ions and nutrients.

The specific conductance of water samples collected in January 1986 ranged from 70 to $440 \mu \mathrm{S} / \mathrm{cm}$ (microsiemens per centimeter). Water that is not affected by agricultural chemicals generally has a specific conductance less than $100 \mu \mathrm{S} / \mathrm{cm}$ with corresponding nitrate con- centrations less than $3 \mathrm{mg} / \mathrm{L}$ (milligrams per liter). Initial laboratory analyses indicate that nitrate concentrations directly correlate with specific conductance in water affected by agricultural chemicals. Concentrations of nitrate as nitrogen and specific conductance ranged from 24 to $37 \mathrm{mg} / \mathrm{L}$ and 302 to $420 \mu \mathrm{S} / \mathrm{cm}$, respectively, in samples from six wells. Increased concentrations of other chemical constituents, including calcium, magnesium, potassium, chloride, and sulfate, also are attributed to agricultural practices.

The concentration of dissolved constituents generally decreases with depth in the aquifer, except in the piczometers adjacent to the irrigation well where the largest changes in specific conductance occur over time. Water in the 25-foot-deep piezometer near the irrigation well had a lower specific conductance than water in the 45-foot-decp piezometer. Changes in specific conductance over time and increasing specific conductance with depth are related to the large vertical component of flow caused by the irrigation well during pumping. Although concentrations of dissolved constituents generally decrease with depth ir. the aquifer, specific conductances greatcr than $300 \mu \mathrm{S} / \mathrm{cm}$ have been measured in water from a piezometer located on the perimeter of the ficld that is screened ncar the base of the aquifer. 


\title{
EFFECTS OF AGRICULTURAL-MANAGEMENT PRACTICES ON SURFACE AND GROUND-WATER QUALITY OF A SMALL CARBONATE BASIN, CONESTOGA RIVER BASIN, PENNSYLVANIA
}

\author{
Patricia L. Lietman \\ U.S. Geological Survey \\ Water Resources Division \\ 840 Market Street \\ Lemoyne, PA 17043
}

\begin{abstract}
The purpose of this investigation is to assess the effects of agricultural BMPs (best management practices) on surface- and ground-water quality of a small carbonate basin. This study is one of three components of a project conducted by the U.S. Geological Survey, and is part of the national Rural Clean Waters Program administered by the U.S. Department of Agriculture in cooperation with the Pennsylvania Department of Environmental Resources.
\end{abstract}

The 22-acre basin is part of a dairy farm. The farm is underlain by weathered and fractured dolomite, which is the parent material for the deep, residual silt loam and silt clay loam soils. The basin is planted in corn ( 80 percent) and alfalfa ( 20 percent); the average land slope is 6 percent. Under the BMP plan for this farm, terraces and a manure-storage facility were constructed, and nutrient-management practices were implemented in the fall of 1984 .

Sampling began in January 1983 and will continue through November 1987. Five wells and one spring are sampled for nutrients about every 3 wceks and during several major ground-water-recharge periods each year. Continuous water-level recorders are installed on the wells. Runoff quantity is measured for all storms, and nutrients are sampled for all major storms. Data for precipitation amounts, manure application and nutrient value, and soil nutrients are collected and land-use records are kept.

Water level in the wells responds quickly to precipitation; increases occur as early as several hours after ranfall begins, and water levels generally peak within 1 day after the rainfall ends.
Preliminary data were analyzed to compare data collected before (pre-BMP) and after (post-BMP) BMP implementation. The following are results of that analysis.

Water levels were lower during the post-BMP than during the pre-BMP phase because of less precipitation and a decreass in infiltration that increased runoff during the post-BMP May-October growing season. Reduced infiltration was probably caused by a buildup of silt and clay behind the terraces during a storm that produced 3 inches of rainfall in 45 minutes in May 1985 . Construction of the terraces also disturbed the soil structure in the basin.

Mean nitrogen concentrations in the wells increased by 4 to 9 percent during the post-BMP phase. This increase in concentration, however, may be related more to the reduction in infiltration (less dilution) after the May storm than to the implementation of BMPs.

Mean total nitrogen concentrations and loads in runoff for storms during the growing season were considerably higher during the post-BMP phase. The nitrogen in runoff during the pre-BMP phase was mostly organic nitrogen. The predominant form of nitrogen in most storms during the post-BMP phase was nitrate-nitrogen.

Mean suspended-sediment and total phosphorus concentrations and loads in runoff for storms during the growing season were slightly lower during the post-BMP phase. This is probably an effect of terracing because much of the sediment and associated phosphorus settles out of the runoff in the retention pools behind the terraces.

[Note: Final data analysis of this 7-year study in some cases suggests different conclusions than the preliminary analysis presented in this abstract written after only 4 years of data collection. The final results of this study will be presented in a USGS report.] 


\title{
A COMPARISON OF SELECTED WATER-QUALITY CHARACTERISTICS IN ACCOUNTING UNIT 070102, UPPER MISSISSIPPI RIVER BASIN, ROYALTON TO HASTINGS, MINNESOTA
}

\author{
Mark R. Have \\ U.S. Geological Survey \\ Water Resources Division \\ 702 Post Office Building \\ St. Paul, MN 55101
}

Hydrologic accounting unit 070102 includes seven subbasins in east-central Minnesota that cover an area of 8,500 square miles. Results of a study, using data from the Minnesota Pollution Control Agency, Metropolitan Waste Control Commission, and U.S. Geological Survey, indicate that selected water-quality characteristics differ significantly among subbasins. Results of that study also indicate that the quality of water leaving the accounting unit at Hastings is affected primarily by inflow from the Minnesota River and by effluent from the Metropolitan wastewater-treatment plant.

Subbasins in the western part of the accounting unit are underlain by prairie soils, and cultivation of row crops is a common land use. Streams draining these subbasins have a median dissolved-solids concentration of $389 \mathrm{mg} / \mathrm{L}$ (milligrams per liter) and a median concentration of nitrite plus nitrate nitrogen of $0.59 \mathrm{mg} / \mathrm{L}$.

Subbasins in the northern and eastern parts of the accounting unit are underlain by more acidic podzol soils. Land use in these subbasins is less devoted to cultivated crops; forested areas, pastures, and wetlands are common. Streams draining these subbasins have a median disolved-solids concentration of $184 \mathrm{mg} / \mathrm{L}$ and a median concentration of nitrite plus nitrate nitrogen of $0.17 \mathrm{mg} / \mathrm{L}$.
The quality of water changes dramatically in the most downstream subbasin, which includes the Twin Cities Metropolitan Area. Based on hourly data from automatic monitors, specific conductance increases from $345 \mu \mathrm{S} / \mathrm{cm}$ (microsiemens per centimeter) above the conflucnce with the Minnesota River to $467 \mu \mathrm{S} / \mathrm{cm}$ bclow. Specific conductance again increases to a median of $513 \mu \mathrm{S} / \mathrm{cm}$ where effluent from the Metropolitan wastewater-treatment plant enters the Mississippi River.

Dissolved-oxygen concentrations in the Mississippi River begin to decline below the confluence with the Minnesota River. Concentrations of dissolved oxygen reach a minimum median value in summer of $6.3 \mathrm{mg} / \mathrm{L}$ at a point about 9 miles downstream from the Metropolitan wastewater-treatment plant. In winter, the point of minimum median concentration shifts downstream to Lock and Dam 2, which is approximately 20 miles below the plant.

Results of this study show that the quality of water in the Mississippi River as it leaves the accounting unit at Hastings is not representative of water quality in most of the area. Hydrologic accounting unit 070102 can be divided into three regions on the basis of water quality. Sampling sites are needed in each region to adcquately assess the quality of streams throughout the accounting unit. 


\title{
AUTOMATED DATA RETRIEVAL AND PROCESSING SYSTEM - (ADAREPS)
}

\author{
Peter Hughes, \\ U.S. Geological Survey \\ Water Resources Division \\ 6417 Normandy Lane \\ Madison, WI 53719
}

The Wisconsin District of the U.S. Geological Survey (USGS) has procured the necessary equipment and has developed the required computer software to implement a real-time hydrologic and metcrologic data-collection system for use in comprehensive nonpoint-source runoff sampling programs. The present system design uses a Campbell Scientific CR21X (1) data logger linked to a line-powered 1200 baud-telephone modem for intelligent sampling of environmental parameters with data retrieval by the telephone line direct to the District central computer.

The CR2IX is a textbook sized, dc-powered precision datalogger. It is a combination of a microcomputer, clock, multimeter, calibrator, scanner, frequency counter, controller, and signal generator. The CR21X includes 16 single-ended analog inputs, 4-pulse counting inputs, 4 switched excitation outputs, 2 continuous analog outputs and 6 digital-control outputs. There are 24 commands for measurements and control output, 39 commands for data processing, and 11 commands for program control. Data storage includes 72 locations for input and user-processed data, 64 locations for intermediate values, and storage for up to 19,400 final data values. The unit can be connected to cassette tape, a memory module, and to serial data-communication equipment.

The USGS has used the CR2IX as the interrogator, datastorage device, and water-quality-sampler controller at data-collection sites that are remote from the servicing offices, because the CR21X can be remotely interrogated and reprogramed through the central office computer. This is essential because local observers can be advised to visit the site and remove the water samples within the required maximum holding times. The remote programming allows the project manager to change the sampling frequencies or threshold stages, depending on the river systems response to runoff events.

The water-quality-sampling program can be tailored to the specific needs of the monitored site. Generally, the automated water-quality sampler is stage activated and is set to sample at uniform time intervals when stage is above the threshold level. With the CR21X, the sampler can be controlled to sample at different frequencies, depending on the stage, and also can be triggered at a specific increment or decrement of stage. If a linear discharge-to-stage rating is available for the site, the CR2IX also can control the sampler on a flowproportional basis.

Use of the CR21X minimizes the time-correction problems created by use of mechanical recorders and multiple recorders because the data is tagged with the day and time at the moment it is sampled. The interfacing of the CR21X to the District central computer through the ADAREPS programs provides the project manager with a daily update of the site data and automatically stores the data in a disk file. Utility programs are available to check the data and plot it both on several CRT and hard-copy devices. Viewing the data gives the manager the opportunity to detect data-collection problems and implement the corrective procedures . 


\title{
AN AUTOMATED METHOD FOR SUBDIVIDING SUSPENDED-SEDIMENT AND CHEMICAL RECORDS
}

\author{
Janice R. Ward \\ U.S. Geological Survey \\ Water Resources Division \\ 810 Bear Tavern Road, Suite 206 \\ West Trenton, NJ 08628
}

\begin{abstract}
Daily and storm concentrations and loads of suspended sediment and other chemical constituents are automatically calculated using a Numonics electronic digitizer and ASUBSED (Automated method for SUBdividing suspended SEDiment and chemical records) and a Fortran program on the PRIME, Pennsylvania District's central computer. ASUBSED will subdivide any given period of record and create a PRIME file of values used for each interval calculation. It then computes and prints the total constituent discharge and average concentration, either time-weighted, water-weighted, or both, for the selected period. Digitized streamflow data for the same intervals may be recalled for calculations of constituent loads . ASUBSED will create a file of each computed water discharge, average concentration, and constituent load that can be stored by site and expanded sequentially for further data analyses. The files produced by ASUBSED can be spooled for permanent record.
\end{abstract}

Data can be digitized from graphic records, computergenerated plots, such as TELEGRAF, or hand-drawn plots. Streamflow data can be digitized from a flow hydrograph plotted with a standardized TELEGRAF procedure or from gage heights that ASUBSED converts to discharges using a stored rating table. Suspendedsediment and chemical-constituent data are retrieved from WATSTORE and plotted by TELEGRAF or by hand. The standardized TELEGRAF procedure plots only data points; it will not draw a curve. Curve fitting is not done automatically because estimations may need to be made between data points. Hand-drawn curves also require a check for erroneous data that might be missed if the curves were drawn automatically.

ASUBSED reduces the time required for computing subdivided records by more than 50 percent. ASUBSED also standardizes computations to eliminate any individual biases that may occur during manual computations. The results of test runs on several sizes of streams compared favorably with manual computations. Daily flow records computed by ASUBSED also compared favorably with flows computed by the interim ADR (Automatic Digital Recorder) processing system.

\section{RELIABILITY OF WATER QUALITY PREDICTED FROM REGRESSION EQUATIONS}

\author{
Jeffrey D. Martin \\ U.S. Geological Survey \\ Water Resources Division \\ 5957 Lakeside Boulevard \\ Indianapolis, IN 46278
}

The use of regression to express relations among waterquality variables or between a water-quality variable and streamflow is becoming more common in U.S. Geological Survey reports. Usually, the regression equation is published along with statistical measures of the goodnessof-fit of the regression (the coefficient of determination ( $r$-square) and the standard error of regression). Regression equations are usually published to allow the reader to predict, for example, a value of specific conductance from a known value of streamflow. The reliability of the predicted specific conductance cannot be determined from measures of the goodness-of-fit of the regression.

Therefore, confidence intervals are presented as a method for estimating the reliability of water quality that has been predicted from regression equations.

Confidence limits for a predicted water-quality value are the expected range of values within which the true value should lie. Confidence limits are always associated with a probability that expresses the degree of confidence that 
the true value is contained within the expected range. Most commonly, 95-percent confidence limits are calculated, but other probabilities may be used. A tradeoff occurs between the degree of confidence and the width of the expected range. If 99 -percent confidence limits are calculated, there is a 4-percent greater certainty that the expected range contains the true value than if the 95-percent confidence limits were chosen, however, the expected range of values for the 99-percent confidence limits is considerably wider than that for the 95-percent confidence limits.

For a given level of confidence, the width of the confidence interval is a measure of the reliability of the predicted water-quality value. Predictions with wide confidence intervals are less reliable than those with narrow confidence intervals. A prediction from a value of the independent variable near the mean of the data used to develop the equation is more reliable than a prediction made from a value near the extremes of the data. This difference in reliability occurs because the regression line must pass through the mean of the independent variable, and uncertainty about the true slope of the line defining the relation manifests itself to a greater degree at the extremes of the data.

Two types of confidence limits can be calculated: limits for the predicted mean value and limits for a predicted individual value. The predicted water-quality value is the same for both cases, but the confidence interval is narrower for the mean value than for an individual value. An analogy can be made between the two types of confidence limits and the mean and standard deviation of a sample: the standard error of the mean is much smaller than the standard deviation of individual items. The type of confidence limit to use may best be described by an example. If the user wants to predict the average specific conductance that occurs whenever a particular streamflow is attained (the 7-day, 10-year low flow, for example), confidence limits for the mean specific conductance value must be used. If the user wants to predict the specific conductance during a particular streamflow on a particular day (the most recent 7-day, 10-year low flow, for example), confidence limits for an individual value must be used. Computer programs that allow the data analyst to calculate confidence limits are presented. Formulas and statistics necessary to allow the report user to calculate confidence limits are discussed. The relation between the standart error of regression and the width of the confidence interval is illustrated by examples. Simple linear regression (one independent variable) is used for ease of comprehension. Methods for multiple regression are briefly summarized. Information for this talk is excerpted from Martin and Crawford (1986, Statistical analysis of surface-water-quality data in and near the coal-mining region of southwestern Indiana: U.S. Geological Survey Water-Supply Paper 2291).

\section{THE MANAGEMENT AND USE OF ORGANIC NONPRIORITY-POLLUTANT DATA}

\author{
Eric F. Vowinkel \\ U.S. Geological Survey \\ Water Resources Division \\ 810 Bear Tavern Road, Suite 206 \\ West Trenton, NJ 08628
}

The thousands of organic compounds not included on the U.S. Environmental Protection Agency's list of Priority Pollutants can provide valuable information of groundwater contamination. The Central Laboratory of the U.S. Geological Survey analyzes water samples for organic nonpriority pollutants, but the format of the data reports received from the laboratory discourages use of the data. A method for storing and reporting organic nonpriority-pollutant data using the INFO computer language has been developed. Data are entered into the INFO files with either a simple INFO input form or a temporary data template in conjunction with an INFO

\author{
Jane Kozinski and Joseph J. Hochreiter, \\ Formerly with U.S. Geological Survey \\ Water Resources Division \\ 810 Bear Tavern Road, Suite 206 \\ West Trenton, NJ
}

program. Managing and reporting organic nonpriority pollutants using the INFO data-filing system facilitates the analysis of these data. A ground-water-quality study at four hazardous-waste disposal facilities in Logan Township, New Jersey has demonstrated the usefulness of this data-management system and the value of using the organic nonpriority-pollutant data in characterizing contaminant plumes. Up to 98 percent of the organic compounds tentatively identified in samples from selected monitoring wells were not priority pollutants. The study identified almost four times the number of organic nonpriority pollutants (192) than priority pollutants (52). 


\section{THE IMPORTANCE OF ORGANIC MATTER IN THE INTERPRETATION OF SURFACE-WATER SEDIMENT DATA}

\author{
James A. Smith \\ U.S. Geological Survey \\ Water Resources Division \\ 810 Bear Tavern Road, Suite 206 \\ West Trenton, NJ 08628
}

\author{
P.J. Witkowski and T. V. Fusillo \\ Formerly with U.S. Geological Survey \\ Water Resources Division \\ West Trenton, NJ
}

Studies investigating the sorption of nonionic organic compounds to surface-water sediments were reviewed. Available data indicate that nonionic organic compounds are not sorbed to sediments by an adsorption process, but by a partitioning process. The nonionic solute partitions itself between water and the sediment-associated organic matter similar to the way it would partition itself between water and an organic solvent such as octanol. As a result, the organic-matter content of sediment is the single most important factor influencing the sorptive capacity of surface-water sediments. Sediment characteristics such as the proportions of sand, silt, and clay, cation-exchange capacity, and particle surface area have no direct, significant influence on a sediment's ability to sorb nonionic organic compounds in aqueous systems.

Unless accounted for, variations in the organic matter content of sediments may mask spatial contamination trends in surface-water systems. To eliminate this likelihood, the bulk-sediment concentration of a contaminant should be normalized for the organic-matter content by dividing by the percentage of organic matter in the sediment sample and then multiplying by 100 . Variations in the normalized concentration will more accurately reflect variations in the exposure of the sediment to the contaminant rather than simply reflecting variations in the organic-matter content of the sediment. All analytical determinations can be performed on the bulk sediment.
Isolation and subsequent analysis of individual size fractions of a bulk sediment sample are costly, time consuming, and usually unnecessary unless the hydrodynamic transport of the sorbed contaminant is to be determined. Even then, a cost-effective alternative exists. The bulk sample can be divided into two parts: one part is analyzed for a range of organic contaminants, and the second part is size fractionated so that the organic matter content of each size range can be determined. The distribution of the mass of organic contaminants in the various size ranges will be approximately proportional to

For a given sediment, increased solute solubility will correlate with decreased sorption. Low-solubility compounds, such as DDT, benzo(a)pyrene, and the PCBs, will strongly partition into sediment organic matter, whereas highly soluble compounds, such as 1,2-dichlorobenzene or 1,2-dichloroethane, will not. Using empirically determined relations, order-of-magnitude approximations of a contaminant's concentration in the sediment may be possible from a knowledge of the contaminant's solubility, its aqueous concentration, and the organic matter content of the sediment. Analysis of data indicates that low-solubility nonionic organic compounds also can partition into dissolved organic matter, this can result in significant solubility enhancements of these compounds. Organic matter, therefore, plays an extremely important role in determining the distribution of nonionic organic compounds in surfacewater systems. 


\section{EQUATION TO ESTIMATE REAERATION COEFFICIENTS IN MASSACHUSETTS STREAMS}

\author{
Gene W. Parker \\ U.S. Geological Survey \\ Water Resources Division \\ 28 Lord Street, Suite 280 \\ Marlborough, MA 01752
}

\author{
Frederick B. Gay \\ Formerly with U.S. Geological Survey \\ Water Resources Division \\ Marlborough, MA
}

An equation for estimating stream reaeration coefficients from easily measured physical characteristics was developed for moderately-sloped streams in Massachusetts. To define the equation, multiple-regression techniques were applied to thirty data sets containing nine physical, hydrologic, and water-quality characteristics. Data on mean depth, water-surface slope, and mean streamflow velocity ranged from 0.4 to 6.3 feet, from 0.00017 to 0.015 feet per feet, and from 0.13 to 2.15 feet per second, respectively. Reaeration coefficients were measured using a steady-state propane-gas tracer technique during medium- and low-flow periods in 1983-84. Measured reacration coefficients ranged from 0.4 to 67.7 base units per day at 20 degrees Celsius. The result of the regression analysis is the relation between the reaeration coefficient $\left(\mathrm{K}_{2}\right)$ and the independent variables, mean depth (D), water-surface slope (SL), and mean streamflow velocity $(\mathrm{V})$, given by: $\mathrm{K}_{2}=252.2 \mathrm{D}^{-0.176} \mathrm{~V}{ }^{0.355}$ $\mathrm{SL}^{0.438}$, in which 252.2 is the regression constant for the equation. The equation was limited to three variables that were the most significant at the 95 - percent confidence level because of the limited size of the data base. The standar 1 error of estimate for the reaeration equation is 37 percent. An error-analysis technique was used to compare the proposed equation with 19 reaeration-coefficient equations in the literature. The error analysis indicates that the proposed equation has the lowest error (27 percent) for 20 stream reaches having slopes greater than 0.002 feet per foot.

\section{RELATION OF POLYCHLORINATED BIPHENYL TRANSPORT IN THE UPPER HUDSON RIVER TO POLYCHLORINATED BIPHENYL CONCENTRATIONS IN RIVER BIOTA}

\author{
Charles R. Bames \\ Formerly with U.S. Geological Survey \\ Water Resources Division \\ Albany, NY
}

\author{
Mark P. Brown and Ronald J. Sloan \\ New York State Department of \\ Environmental Conservation \\ Albany, NY 12201
}

The fate of a chemical in natural aquatic systems is governed by complex relations between the properties of the substance and its environment. An understanding of these relations is important in predicting the transport and availability of environmental pollutants. Discharge of polychlorinated biphenyls (PCBs) during 1950-77 has resulted in the degradation of water quality in a 50-kilometer reach of the upper Hudson River, where 160,000 kilograms of PCBs were estimated to remain in the river sediments in 1977. Monitoring of water and biological quality in the upper Hudson River has provided a continuous record of the natural recovery of the river and the movement of PCBs from riverbed sediments into the water column and their uptake by biota.

The fate of persistent organic compounds, such as PCBs, is greatly influenced by the transport mechanisms between sediment and overlying water and by diffusion in interstitial water. When river discharge is sufficient to induce scour, resuspension of PCB-laden sediments is the principal mechanism of entry to the water, whereas at lower flows, desorption of PCBs from sediments and diffusion to the water column at an annually constant rate is the principal mechanism. During scour periods, the 
more highly chlorinated congeners predominate, where as at low flows, mono-, di-, and trichlorinated congeners of PCBs predominate. The loss of the less highly chlorinated congeners by volatilization and, to a lesser extent, by dechlorination, has caused the relative abundance of the highly chlorinated congeners to increase with downstream distance in the estuary.

- Approximately 11,000 kilograms of PCBs were transported to the estuary during 1977-85. Data from nonscour periods indicate an 85-percent reduction in PCBtransport rates during 1977-85, from approximately $5.8 \mathrm{~kg} / \mathrm{d}$ (kilogram per day) to less than $1 \mathrm{~kg} / \mathrm{d}$. This decline is the result of remedial actions and natural processes such as deposition of fresh sediments over contaminated sediments, depletion of PCBs from the diffusional surface layer, and insufficient mixing to bring deeper contaminated sediments into contact with the overlying water. PCB-transport rates during periods of high flow may range from $5 \mathrm{~kg} / \mathrm{d}$ to more than $150 \mathrm{~kg} / \mathrm{d}$. Although the variability of such factors as the magnitude and duration of individual high flows, and of the subbasin in which most of a given flow originates, are impediments to identification of long-term trends in scour-related PCB-transport rates, a 50-percent reduction since 1977 in PCB transport during high flows is indicated. This estimate was obtained by normalizing PCB concentrations to suspended sediments and then analyzing them as a function of subbasin flows.

Decrease in PCB concentrations in Hudson River fish, caddisfly larvae, and multiplate residues were also observed during 1977-84. In fish from the upper river, less highly chlorinated PCBs, once the dominant congeners, have decreased by 80 to 90 percent, while the more highly chlorinated compounds also have decreased, but to a significantly lesser extent. Lipid concentrations in yearling pumpkinseed (Lepomis gibbosus) were highly correlated with mean annual $\mathrm{PCB}$ concentrations in water during nonscour periods. Estuarine species had proportionately higher levels of the more chlorinated congeners and less overall reduction of PCB content than fish from the upper basin. These results indicate a relation between $\mathrm{PCB}$ transport during nonscour periods and $\mathrm{PCB}$ accumulation in fish from the upper basin, and $\mathrm{PCB}$ transport during scour periods and $\mathrm{PCB}$ concentrations in fish from the estuary.

\title{
WATER-QUALITY TRENDS OF MAJOR RIVERS IN WEST VIRGINIA
}

\author{
Theodore A. Ehlke, \\ U.S. Geological Survey \\ Water Resources Division \\ 810 Bear Tavern Road, Suite 206 \\ West Trenton, NJ 08628
}

Coal mining, acid precipitation, industrial and municipal wastewater discharges and road-deicing chemicals have caused changes in the water quality of streams throughout the State since 1965 . This paper discusses chemical trends and transport in major rivers from 1965 to the present. Improved storage of road-deicing chemicals probably is a major cause of decreased sodium and chloride concentrations in the Potomac River. The river transported a high quantity of dissolved solids from the basin in $1984,81.8 \times 10^{3} \mathrm{~kg} / \mathrm{km}^{2} / \mathrm{y}$. (kilograms per kilometer squared per year). Most of the solute load was bicarbonate from the solution of massive limestone deposits in the basin.

The West Fork and Tygart Valley Rivers in the Monongahela River basin have an increasing trend in $\mathrm{pH}$ and alkalinity because of improved reclamation and mining techniques. The West Fork River drains an area which has been heavily coal mined since the 1800 's. For this reason the dissolved solids yield for the West Fork River was the highest for any river in the State in 1984, $144.7 \times 10^{3} \mathrm{~kg} / \mathrm{km}^{2} / \mathrm{y}$, or about $2.58 \times 10^{8} \mathrm{~kg}$, most of which was sulfate.

Increased coal mining in the headwaters of the Little Kanawha River probably is a major reason for a decreased $\mathrm{pH}$ trend and increased sulfate concentration since 1968. Improved storage of road deicing chemicals may have influenced the decreased calcium and sodium concentrations.

The Kanawha River is formed at the confluence of the New and Gauley Rivers at Gauley Bridge, and flows northwestward into the Ohio River through a heavily industrialized area of chemical manufacturing. The Greenbrier, Elk, Pocatalico, and Coal Rivers are major tributaries to the Kanawha River. Based on analysis of available data, no significant chemical trends in the 
Grcenbrier River are evident. Increases in calcium concentration in the Gauley River as well as increased specific conductance, sodium, and calcium concentrations in the Elk River; and increased alkalinity in the Coal River have occurred since 1970. Acid precipitation probably is the source of about one-third of the sulfate which was transported out of the Elk River basin in 1984. Specific conductance and the concentrations of sodium and calcium are increasing in the lower portion of the Elk River basin, probably because of runoff from roaddeicing chemicals during the winter.

Water quality in the Kanawha River has improved in many aspects since the early 1970's. The specific conductance has decreased about 27 persent since 1974, and concentrations of dissolved solids, calcium, sodium, chloride, bicarbonate, and sulfate are decreasing. This improvement is partially due to improved treatment of mine discharges on the tributaries and to major improvements in the quality of wastewater discharges from chemical manufacturing plants and municipalities along the Kanawha River.

In southern West Virginia, specific conductance in the Guyandotte River is decreasing, probably because of storage in a new reservoir near Justice. Coal mining in the Tug Fork basin probably is largely responsible for the increasing trend in specific conductance and sulfate concentration in drainage into the Big Sandy River.

\section{WATER QUALITY TRENDS IN WHITE RIVER NEAR INDIANAPOLIS, INDIANA: EFFECTS OF ADVANCED TREATMENT OF MUNICIPAL WASTEWATER}

\author{
David J. Wangsness \\ U.S. Geological Survey \\ Water Resources Division \\ 6481-B Peachtree Industrial Blvd. \\ Doraville, GA 30360
}

\author{
Charles G. Crawford \\ U.S. Geological Survey, \\ Water Resources Division \\ 5957 Lakeside Boulevard \\ Indianapolis, IN 46278
}

The City of Indianapolis has constructed state-of-the-art municipal, advanced wastewater-treatment systems to enlarge and upgrade the existing secondary-treatment facilities at its Belmont and Southport treatment plants. Nonparametric statistical procedures were used to test for trends in time-series water-quality data from four sites on White River and from the Belmont and Southport treatment plants. Time-series data that represented conditions before and after advanced wastewater treatment were tested for trends; results indicate very substantial improvements in water quality of treated effluent and of White River downstream from Indianapolis after implementation of advanced wastewater treatment. Water quality at sample sites located upstream from the wastewater-treatment facilities was relatively stable during the period of study (1977-85). Analysis of data collected at the plants and downstream from the plants indicates statistically significant decreasing trends in concentrations of total ammonia, 5-day biochemicaloxygen demand, fecal-coliform bacteria, total solids, and total phosphate at all sites where enough data were available for testing. Because of in-plant nitrification, nitrate concentrations increased at statistically significant rates in both the plants and in White River. The decrease in ammonia concentrations and 5-day biochemicaloxygen demand in White River resulted in a statistically significant increasing trend in dissolved-oxygen concentration because of reduced oxygen demand for nitrification and biochemical-oxidation processes. Following implementation of advanced wastewater treatment, the number of river-quality samples that exceeded the waterquality standards for fecal coliform bacteria, ammonia, and dissolved oxygen that apply to White River decreased substantially. 


\title{
DETERMINATION OF BENTHIC-INVERTEBRATE INDICES AND WATER-QUALITY TRENDS OF SELECTED STREAMS IN CHESTER COUNTY, PENNSYLVANIA, 1969-80
}

\author{
Craig R. Moore \\ Formerly with U.S. Geological Survey \\ Water Resources Division \\ Malvern, PA
}

The trends of biological and chemical data collected for 12 years (1969-80) from 46 sites in Chester County were evaluated by the seasonal Kendall test. Brillouin's diversity index was calculated and plotted as a function of time for each site. The diversity index at seven sites had upward trends significant at the 99-percent confidence level, the index at nine sites had upward trends significant at the 95- to 98-percent confidence level, and the index at 11 sites had upward trends significant at the 90- to 94-percent confidence level. Although the diversity indices were not statistically significant, 17 of the remaining sites had upward trends and two had downward trends.
The seasonal Kendall test was used to test the chemical data for temporal trends at eight sites for which streamdischarge data were available. Significant trends were found at one or more sites for flow-adjusted values of specific conductance, $\mathrm{pH}$, total nitrate, total phosphorus, dissolved chloride, and dissolved sulfate. The chemical data for 11 sites, which were not flow adjusted, were tested for trends. The chemical data was plotted as a function of time, and a correlation coefficient was determined. Significant trends were found at one or more sites for nitrate and chloride. Selected chemical constituents were tested by regression analysis for correlation with the diversity index. Only total dissolved solids correlated significantly with diversity index. Based on the statistical analysis, several suggestions are made to improve the monitoring program.

\section{REGIONAL WATER-QUALITY TRENDS AND OFFSHORE EXTENT OF FRESHWATER IN THE 800-FOOT SAND OF THE KIRKWOOD FORMATION, ATLANTIC CITY AREA, NEW JERSEY}

\author{
Jeffrey S. Clark \\ U.S. Geological Survey \\ Water Resources Division \\ 8600 LaSalle Road \\ Towson, MD 21204
}

\begin{abstract}
Large withdrawals of water from the 800 -foot sand of the Kirkwood Formation in the Atlantic City area, New Jersey, have lowered ground-water levels as much as 90 feet below prepumping levels. This pumping has created an extensive cone of depression and heightened the potential for contamination, particularly by intrusion of seawater. To evaluate the likelihood of such contamination, the U.S. Geological Survey, in cooperation with the New Jersey Department of Environmental Protection, began a study in 1984 to assess the quality and extent of fresh ground water in confined parts of the 800-foot sand.
\end{abstract}

Two marine observation wells were constructed at sites 1.9 miles and 5.3 miles offshore of Atlantic City, primarily to determine the seaward extent of fresh ground water. These wells, in addition to 70 other wells onshore from Barnegat Light, Ocean County, on the north to
Wildwood, Cape May County, on the South, were sampled for determination of major ions, nutrients, selected trace metals, and volatile organic compounds. Samples from the offshore wells also were analyzed for stable isotopes and dissolved gases. Water from the well 1.9 miles offshore had a specific conductance of 220 microsiemens per centimeter and a chloride concentration of 15 milligrams per liter, whereas that from the well 5.3 miles offshore had a specific conductance of 502 microsiemens per centimeter and a chloride concentration of $\mathbf{7 7}$ milligrams per liter. At the conclusion of sampling, three specific-conductance sensors and three differential-pressure transducers were permanently installed in each offshore well. Periodic monitoring of the downhole sensors is planned to measure dissolved solids and water levels, and to detect any encroachment of saline water toward onshore freshwater supplies. 
Chemical analyses of ground-water samples collected in a northeast to southwest direction (parallel to strike), and in a northwest to southeast direction along the principal flow path (down dip), indicate the general regional waterquality trends and characteristics. Increases in specific conductance and $\mathrm{pH}$ from north to south and from west to east are thought to be related to an increase in the amount of carbonate material in the sediments underlying present-day coastal areas. These increases are accompanied by changes in hydrochemical facies from a predominantly calcium-bicarbonate-sulfate water to a sodiumbicarbonate water. The facies changes are believed to be caused by the interaction of ground water with sediments deposited in an increasingly marine environment. These fine-grained sediments of marine origin may promote the opportunity for increased rates of cation exchange. Water collected from the well 5.3 miles offshore is predominantly a sodium-bicarbonate-chloride type, which is likely due to the proximity of the well to the freshwater-saltwater interface. Preliminary results of the study indicate that a large body of freshwater is present in the inland parts of the 800-foot sand and extends several miles seaward from Atlantic City. Analytical results also indicate that, overall, the quality of water in the aquifer is suitable for most purposes.

\title{
COMPARISON OF THREE TYPES OF WATER-QUALITY MONITOR SYSTEMS
}

\author{
Max S. Katzenbach, \\ U.S. Geological Survey \\ Water Resources Division, \\ 975 West Third Avenue \\ Columbus, $\mathrm{OH} \quad 43212-7139$
}

The U.S. Geological Survey flow-through water-quality monitor has long been the standard system for continuous collection of specific-conductance, dissolved-oxygen, temperature, and $\mathrm{pH}$ data for streams. Flow-through systems are costly to operate because of (1) the time required to calibrate all four sensor probes separately, (2) the need for a pumping system to bring water from the stream to the gage house, and (3) the need to control the environment inside the gage house. The pumping system in and of itself requires a substantial amount of labor for installation, maintenance, and repair. Furthermore, failure of the pumping system can cause loss of record, as can failure of sensing or recording equipment.

The Geological Survey's minimonitor makes use of in situ sensors, thus eliminating the need for the pumping system; however, the calibration procedure is at least as time consuming as for flow-through systems, if not more so. Hydrolab Corporation has recently developed a prototype packaged sensor system, which combines selfcalibrating, in situ sensors, a battery-operated power supply, and a recording device into one self-contained, immersible unit. Although it seems obvious that the Hydrolab system would be much easier and much less costly to operate than either the flow-through monitor or the minimonitor, a thorough comparison of the three systems is needed to accurately determine cost differences and evaluate the miscellaneous technical problems associated with each.

The purpose of this study - which has been funded through the Survey's Hydrologic Instrumentation Facility (HIF) - is to make such a comparison. A U.S. Geological Survey minimonitor and a Hydrolab packaged-sensor unit have been installed at each of four flow-through monitor sites in Ohio. Each system will be evaluated on the basis of cost of operation and maintenance, quality of data (field-calibration checks compared to office electronic caliration), and completeness of data. Data are scheduled to be collected from October 1985 through September 1986. Preliminary results indicate that the Hydrolab system is superior in terms of ease and cost of operation and maintenance, although difficulties with its power supply and dissolved-oxygen probe need to be resolved. Data from the Hydrolab system compare favorably with those obtained from the flow-through monitors and minimonitors. 


\section{GUIDELINES FOR USING THE STEADY-STATE GAS-TRACER METHOD TO DETERMINE GAS-DESORPTION COEFFICIENTS}

\author{
Gene W. Parker \\ U.S. Geological Survey \\ Water Resources Division \\ 28 Lord Road, Suite 280 \\ Marlborough, MA 01752
}

\author{
Victoria J. Epstein \\ Formerly with U.S. Geological Survey \\ Water Resources Division \\ Marlborough, MA
}

Guidelines and equations to streamline the computations of gas-desorption coefficients in the U.S. Geological Survey steady-state gas-tracer method were developed using a sensitivity analysis. These guidelines were developed to (1) deter-mine how many data points are needed to accurately define a slug-injected dye-tracer response curve at a measurement site, and (2) present a method for evaluating whether the steady-state Taylor-series equation or the steady-state superposition equation should be used to compute gas-tracer desorption coefficients. These guidelines resulted from difficulties that arose in analyzing 30 data sets collected for the Massachusetts Stream Aeration Project MA83-059. During that study, it was not always possible to collect 30 to 50 dye samples over the duration of the upstream dye-cloud. In addition, differences of up to 10 percent in gas-desorption coefficients were noted when both the Taylor-series and superposition equations were used for the same data sets. The following guidelines are suggested to maintain the accuracy of desorption coefficient calculations. To define a conservative dye-tracer response curve, it is suggested that a minimum of 11 data points spread over the entire dye-tracer curve be determined. These data points should include data pairs (dye concentration, traveltime) for leading edge, peak, and the 2 percent of peak concentration trailing edge. Of the two steady-state equations used to determine gas-tracer desorption coefficients, the superposition equation is the more accurate but also the least efficient in terms of time required to do the computations. Gas-desorption coefficients determined using the Taylor-series equation and superposition equation agreed within 5 percent of each other when the plug-flow equation's correction factor required less than 10 moments about the mean of the dye response curve to be determined. Therefore, it is suggested that gas-desorption coefficients be calculated using the steady-state Taylor-series equation as long as the equation's correction-factor determinations require less than 10 response curve moments. If the Taylorseries equation's correction factor requires 10 or more response curve moments for determination, it is suggested that the steady-state superposition equation be used to determine the gas-desorption coefficient. The number of dye-tracer response-curve moments needed to determine the Taylor-series equation's correction factor for a coefficient for the study reach. An equation was developed to estimate the number of moments required to determine the Taylor-series equation's correction factor. A standard error of estimate of 1.4 percent and a correlation coefficient of 0.99 were obtained for this equation. 


\title{
ELECTRICAL POTENTIALS IN WATERS FROM A STREAM-AQUIFER SYSTEM IN A GLACIAL TERRANE NEAR WOOSTER, NORTHEASTERN OHIO - VARIATIONS AND HYDROLOGIC IMPLICATIONS
}

\author{
By Kevin J. Breen, \\ U.S. Geological Survey \\ Water Resources Division \\ 840 Market Street \\ Lemoyne, PA 17043
}

Ficld measurements of electrical potentials developed between a platinum and calomel electrode pair have proven useful as a qualitative geochemical tool for a study of induced infiltration in a semi-confined glacial outwash aquifer-stream system in northeastern Ohio. Potential measurements obtained with an in-line flow cell were used to supplement temperature, $\mathrm{pH}$, dissolved oxygen, and specific conductance as indicators of the evolution of water chemistry during pumping of a well prior to sampling. In an attempt to identify oxidizing surface waters in the ground-water system, potential measurements also were used to compare waters in shallow ground-water flow, streamflowk, and flow from a spring. Potential measurements were incorporated because dissolved-oxygen coancentrations in ground water were typically less than 0.2 milligrams per liter and hydrogen sulfide was not detected.

Potentials were found to stabilize as quickly as other ficld-measured propertics ( 15 to 30 minutes) in water pumped at rates of 1 to 700 gallons per minute from monitor and production wells. Reproducibility of measured potentials was found to be good within a 50-millivolt range during as many as eight separate visits to each of 15 wells over a 10-month period. Potentials measured in water from a well completed in deep glacial drift (70 feet below land surface) unaffected by pumping stress are two to three times lower than potentials in shallow ( 35 feet below land surface) and deep glacialdrift wateis near a pumping stress, and are four times lower than nearby surface waters and a spring water. Three types of ground water were identified solely on the basis of field potential and field $\mathrm{pH}$ measurements. The concentrations of selected inorganic constituents will be compared with measured potentials and discussed in relation to the hydrology of the stream-aquifer system and to the feasibility of incorporating potential measurements of $\mathrm{pH}$, dissolved oxygen, specific conductnace, and temperature.

\section{EFFECTS OF SELECTED SAMPLING EQUIPMENT AND PROCEDURES ON TRICHLOROETHYLENE CONCENTRATIONS IN GROUND-WATER SAMPLES}

\author{
Kenneth A. Pearsall \\ U.S. Geological Survey \\ Water Resources Division \\ 5 Aerial Way \\ Syosset, NY 11791
}

\author{
David A. V. Eckhardt \\ U.S. Geological Survey \\ Water Resources Division \\ 521 West Seneca Street \\ Ithaca, NY 14850
}

Concentrations of trichloroethylene and related compounds in ground-water samples from a sand and gravel aquifer were compared to determine the effect of the type of sampler and how it is used on volatile organic compound (VOC) concentrations. Samples were obtained from three submersible pumps, a centrifugal pump, two peristaltic pumps, and a Teflon bailer and analyzed for VOCs . Results indicate that pump placement, rate of pumping, duration of pumping, and the vertical and lateral distribution of VOCs in ground water near the well screen have a potentially significant influence on VOC concentrations and that these factors can have a greater effect than the type of sampler used.
In sampler tests, 2- and 4-inch-diameter submersible pumps and a centrifugal pump produced samples whose VOC concentrations, on the average, did not differ significantly from each other. Samples from a peristaltic pump used with silicone tubing had significantly lower VOC concentrations than samples from a submersible pump. Concentrations of 1,2-dichloroethylene and trichloroethylene in samples from a Teflon bailer were indistinguishable from those in samples collect by a submersible pump when the concentrations were 96 and 76 micrograms per liter, respectively, but were 15 and 12 percent lower when concentrations were 29 and 23 micrograms per liter. 


\section{FIELD EVALUATION OF SAMPLING DEVICES FOR PURGEABLE ORGANIC COMPOUNDS IN GROUND WATER}

\author{
Thomas E. Imbrigiotta, Jacob Gibs, \\ U.S. Geological Survey \\ Water Resources Division \\ 10 Bear Tavern Rd., Suite 206 \\ West Trenton, NJ 08628
}

Increased concern over organic contamination in ground water has raised questions about the ability of traditional sampling devices to obtain representative samples for organic analyses. One of the most important groups of organic compounds that require collection of representative samples is the purgeable organic compounds (POCs). This group presents special sampling and analytical difficulties because of their low molecular weights, high vapor pressures, and low solubilities in water. These compounds tend to volatilize in systems open to the atmosphere and can be easily stripped from solution by dissolved gases. Previous work evaluating the ability of different sampling devices to recover POCs from ground water has been done only in the laboratory. The objective of this study was to evaluate the ability of seven different sampling devices to recover POCs from ground water under field conditions.

The seven different samplers evaluated were: (1) a gear submersible pump, (2) a helical-rotor submersible pump (3) a bladder pump, (4) a peristaltic pump, (5) a syringe sampler, (6) an open bailer, and (7) a point-source bailer. These devices represent three categories of commercially available ground-water samplers: positive-displacement samplers, suction-lift samplers, and grab samplers. Water-contact surfaces of all sampling devices were stainless-steel, Teflon, glass, or Viton.

Three wells known to contain water with POCs were chosen for intensive field sampling tests-one on Cape Cod, Massachusetts, one in northern New Jersey, and one in southem New Jersey. All three wells were screencd in shallow unconfined aquifers consisting of unconsolidated sands and had hydrostatic pumping heads of approximately 6 feet. The sample recovery depths were 50 feet in the Cape Cod well, 12 feet in the northern New Jersey well, and 19 feet in the southern New Jersey well.

Each well was pumped until field measurements stabilized before sampling for POCs began. Fifteen to 28 replicate samples were collected at each well with

\author{
Thomas V. Fusillo, George R. Kish, and \\ Joseph J. Hochreiter \\ Formerly with U.S. Geological Survey \\ Water Resources Division \\ West Trenton, NJ
}

each of the seven different samplers. These samples were analyzed for purgeable priority-pollutant concentrations by U.S. Environmental Protection Agency Methods 601,602 , and 624 . The mean concentrations obtained with each sampler were compared using analysis-ofvariance testing to determine if the sampling devices differed significantly, at the 95-percent confidence level, in their ability to recover each POC.

Significant differences among the mean concentrations obtained with each sampler were found for selected POCs at each of the sites. The relative order of the samplers from most effective (highest) recovery to least effective (lowest) recovery varied between sites and among compounds detected at a site. A composite ranking of the sampling devices from highest to lowest recovery using data from all three sites yielded the following order:

(1) point-source bailer

(2) gear submersible pump

(3) open bailer

(4) bladder pump

(5) helical-rotor submersible pump

(6) peristaltic pump, and

(7) syringe sampler.

The composite ranks of samplers 1 through 5 were closely grouped, indicating these devices were very similar in their ability to recover POCs.

A similar composite ranking of the coefficents of variation indicated no difference between the sampling devices in the precision with which they recovered POCs. However, the three samplers with the lowest coefficients of variation were all positive displacement pumping devices whereas the three samplers with the highest coefficients of variation were all grab-sampling devices. Coefficients of variation by compound averaged 18 percent for compounds with concentrations above 20 micrograms per liter and 31 percent for compounds with concentrations below 20 micrograms per liter. 


\title{
A STUDY T O EVALUATE THE EFFECTIVENESS OF HIGHWAY-DRAINAGE SYSTEMS IN PREVENTING GROUND-WATER CONTAMINATION
}

\author{
Peter E. Church \\ U.S. Geological Survey, \\ Water Resources Division \\ 28 Lord Road, Suite 280 \\ Marlborough, MA 01752
}

\begin{abstract}
A long term study of the effectiveness of various types of highway-drainage systems in preventing contamination of ground water by highway-deicing chemicals (primarily sodium-chloride and calcium-chloride salts) is currently (1986) being conducted. Four study sites along an unfinished stretch of a six-lane roadway in Massachusetts, cach representing a different type of highwaydrainage system, are bcing instrumented. Independent monitoring programs are bcing developed to determine the quantity of salts (1) applicd to the roadway surface, (2) conveyed from the roadway, median strip, and shoulders in the drainage systems and discharged elsewhere, and (3) entering the unconfined sand-and-gravel aquifer underlying the highway. Systematic datacollection programs are expected to begin in 19871 year prior to the opening of the highway-and continue for 6 years.
\end{abstract}

Salt application to the highway surface will be monitored and maintained as uniformly as possible at all study sites. Chloride-a conservative ion - will be used as a tracer to determine the amount of road salt captured in the highway-drainage systems as well as the amount entering the ground water. Drainage-system monitoring stations, constructed within the central drainage unit at cach site and built over Parmer-Bowlus flumes, will be equipped with compressed-gas supplies, pneumatic-bubbler regulators, pressure transducers, specific-conductance and temperature monitors, constant-rate dye-injection pumps, automatic water samplers, and solid-state microloggers and memory modules. Stage and conductance data will be recorded at 1-minute intervals during runoff events. Water samples from within the drainage systems will be collected periodically during these events by the intomatic samplers. Chloride loads transported from the four study sites in the drainage systems will be estimated by means of stage/discharge and conductance/ chloride rating curves developed from these data. Networks of observation wells, located upgradient and downgradient from the highway, are being screened through the upper half and lower half of the aquifer. Chloride concentrations will be determined from monthly water samples obtained from these wells. The total highway-related chloride load in the ground water at each site will be estimated from these data. In addition, all water samples will be analyzed for sodium and calcium concentrations to evaluate the impact of highway-deicing chemicals on the quality of the ground water, and to allow estimation of the amount of sodium and calcium retained in the unsaturated zone.

\section{MONITOR-WELL INSTALLATION AND INVESTIGATION FOR VOLATILE ORGANICS CONTAMINATION IN MULTILAYERED COASTAL PLAIN AQUIFER SYSTEM OF VIRGINIA}

\author{
Winficld G. Wright \\ U.S. Gcological Survey \\ Water Resources Division \\ P.O. Box 2027 \\ Grand Junction, CO 81502
}

\author{
John D. Powell \\ U.S. Geological Survey \\ Water Resources Division \\ 3916 Sunset Ridge Road \\ Raleigh, NC 27607
}

\author{
David L. Nelms \\ U.S. Geological Survey \\ Water Resources Division \\ 3600 West Broad Street \\ Richmond, VA 23230
}

Volatile organics are present in the multilayered aquifer system underlying the Defense General Supply Center (DGSC), Richmond, Virginia, located on the western edge of the Coastal Plain physiographic province.

Trichlorocthylene, tetrachlorocthylene, chlorobenzene, 1,2-dichloroethane, 1,2-trans-dichlorocthylene in concen- trations as high as 3,200 parts per billion have been detected. The sources of the contamination are assumed to be a former landfill and solvent storage and disposal areas used during the 1950's. Contaminant plumes are migrating from these areas which are located within a 10 to 15 -foot thick unconfined, sand aquifer. Underlying 
this unconfined aquifer is a confining unit 8 to 12 feet thick composed of clay and silt having a hydraulic conductivity of approximately $8.6 \times 10^{-5}$ meters per day. Below the confining unit and overlying granitic bedrock, is a confined aquifer 20 to 30 feet thick composed of sand and gravel. The confined aquifer has been contaminated by downward migration of contaminants from the unconfined aquifer through the confining unit.

Clusters of monitoring wells constructed by the U.S. Geological Survey were used to define the extent of migration of contamination downgradient beyond the boundary of the DGSC. Ten c1usters of wells are spaced in triangular patterns to define the areal extent of contamination migration. Monitoring wells within each cluster are finished with two-foot screens at the bottom, middle, and top of each aquifer to determine the vertical profile of contamination throughout the study area. The confined-aquifer wells were telescoped through the confining unit to prevent interaquifer contamination.

Results from sampling confined-aquifer wells show the presence of volatile-organic compounds with concentrations varying vertically within the aquifer. The higher concentrations of contaminants detected in the lower aquifer occur coincident with zones of more rapid ground-water flow.

Aquifer-test data show transmissivities differ within the top, middle, and bottom parts of the confined aquifer. These differences are significant when estimating the average-linear velocity of ground water and the horizontal extent of the contamination plume.

\section{LARGE-SCALE NATURAL-GRADIENT TRACER TEST IN A SAND AND GRAVEL AQUIFER, CAPE COD, MASSACHUSETTS}

\author{
Kathryn M. Hess, Stephen P. Garabedian \\ and Denis R. LeBlanc \\ U.S. Geological Survey \\ Water Resources Division \\ 28 Lord Road, Suite 280 \\ Marlborough, MA 01752
}

\author{
Richard D. Quadri \\ Formerly with U.S. Geological Survey \\ Water Resources Division \\ Marlborough, MA
}

\begin{abstract}
A large-scale natural-gradient tracer test has been underway since July 1985 as part of an interdisciplinary toxic waste study on Cape Cod, Massachusetts. This test is designed to examine how contaminants are transported and dispersed through sand and gravel aquifers. Treated domestic sewage from Otis Air Base has been disposed by rapid infiltration since 1936 . The resulting plume of contaminated ground water-as defined by depleted dissolved oxygen and by elevated specific conductance, temperature, chloride, sodium, boron, phosphorus, nitrogen, and detergents-is from 2,500 to 3,500 feet wide, 75 feet thick, and more than 11,000 feet long. The natural-gradient tracer test is intended to simulate a contaminant plume, such as that at the Otis site, through a controlled, well-monitored field experiment.
\end{abstract}

The tracer test began with a pulse injection of four chemical tracers on July 18, 1985. Bromide was expected to behave conservatively. The three non-conservative tracers were lithium, fluoride, and molybdate. The injection volume was 2,015 gallons of solution, with concentrations of $640,78,50$, and 80 milligrams per liter for bromide, lithium, fluoride, and molybdate, respectively. In order to monitor changes in tracer concentrations as the cloud is transported downgradient, more than 400 multilevel samplers have been installed to date (March 1986). Each multilevel sampler has been constructed with 15 sampling ports that are spaced 10 to 20 inches apart vertically. Areal spacing of samplers ranges from 3 to 15 feet.

Monitoring will continue with monthly sampling rounds until the cloud is transported out of the study area-approximately 700 feet downgradient from the injection point. Each sampling round has entailed sampling more than 2,000 sampling ports and has taken 2 to 3 days to complete. To date, nine sampling rounds have been completed.

Preliminary results support the assumption that bromide behaves as a conservative tracer. The peak-concentration velocity of the bromide cloud has been 1.6 feet per day, based on analysis of the collected samples. This velocity is similar to the average ground-water velocity -1.5 feet per day-calculated from estimates of hydraulic conductivity ( 380 feet per day), porosity ( 0.35 ) and water-table gradient ( 0.0014$)$. In addition, the average direction of bromide transport has agreed with that predicted from the water-table configuration. 
Detailed analyses of data from early sampling rounds show a complex distribution of bromide. Small-scale hydraulic-conductivity variations within the aquifer create velocity variations which are reflected in the conservative-tracer distribution. The core of the bromide cloud has been moving at approximately 1.6 feet per day, the leading edge at 3 feet per day, and the trailing edge at 0.4 feet per day. This marked difference between leading-and trailing-edge velocities has resulted in rapid longitudinal spreading of the bromide cloud and a decrease of tracer concentration in the cloud. Lateral and vertical spreading have been considerably less. Preliminary comparisons of the molybdate and bromide distributions indicate that molybdenum movement has been measurably slower than that of the conservative bromide, which suggests that molybdate behaves nonconservatively in this aquifer.

\section{WELL DESIGN FOR VERTICAL WATER-QUALITY PROFILING IN A SAND AND GRAVEL AQUIFER, CAPE COD, MASSACHUSETTS}

\author{
Richard D. Quadri \\ Formerly with U.S. Geological Survey \\ Water Resources Division \\ Marlborough, MA
}

\begin{abstract}
Detailed 3-dimensional sampling of ground water to describe the distribution of solutes in a sand and gravel aquifer was needed for solute-transport studies at the site of a plume of sewage-contaminated ground water on Cape Cod, Massachusetts. Three methods have been developed and used to obtain vertical profiles of contaminant distributions: clusters of wells, a screened auger, and multilevel samplers.
\end{abstract}

Prior to 1984 , clusters of wells were the primary monitoring systems used to sample and define the distribution of solutes in the aquifer. These clusters consist of three to seven polyvinyl-chloride (PVC) wells that are 1.25 to 2 inches in diameter with screen lengths of 2 feet. Vertical spacing between individual screens is commonly 20 feet or more. A five-well cluster, with well depths ranging from 40 to $140 \mathrm{fcet}$, costs as much as $\$ 9,000$ to install (1986). Vertical placement of individual well screens in a cluster originally was based upon a "bestguess" strategy whose effectiveness could only be evaluated after the wells were installed and sampled. Often, these screens missed or straddled key zones of contaminant concentration.

Since 1984, the vertical placement of well screens has been guided by field analyses of water samples collected through a screened auger during drilling. The screened auger is a 5-foot-long, 3.25-inch-diameler hollow-stem auger flight that includes a 2-foot-long section of wirewound screen. Water samples can be pumped directly from the auger flights during drilling to obtain a profile

\author{
Denis R. LeBlanc \\ U.S. Geological Survey, \\ Water Resources Division \\ 8 Lord Road, Suite 280 \\ Marlborough, MA 01752
}

of selected field water-quality parameters. This profile is then used to place the screens of permanent monitoring wells at precisely identified depths to intercept sharp concentration gradients or peaks that could be missed by randomly placed well screens. This method is suited only to clean sands and gravels because the auger screen tends to become clogged if silt and clay zones are encountered. Data collected using the screened auger have indicated that zones of peak contaminant concentration in the plume are often less than 5 feet thick.

Multilevel samplers have been used since 1984 where permanent sampling points at vertical spacings of 0.5 to 2 feet are needed to monitor sharp concentration gradients. These multilevel samplers consist of 15 polyethylene tubes, 0.25 inches in diameter, supported inside a 1.25-inch diameter PVC pipe. The small-diameter tubes run down the center of the PVC pipe, protrude through a hole drilled through the pipe, and are screened over 0.1 foot with nylon fabric. Samples can be collected simultaneously from all 15 tubes using a multihead peristaltic pump. Yields from individual tubes typically are 300 to 600 milliliters per minute. Of over 6,500 individual sampling tubes installed at the Cape Cod site, less than 1 percent have failed to yield water. Each multilevel sampler, the equivalent of 15 wells, is installed in a single hole at a cost of about $\$ 3,000$. Vertical variations in concentrations as great as 50 percent over a vertical distance of 10 inches have been detected at the sewageplume site by sampling the multilevel samplers. 